\title{
Petrochronology and hygrochronology of tectono-metamorphic events
}

Valérie Bosse (1), Igor M. Villa (2)

4 (1) Laboratoire Magmas et Volcans, Université Clermont Auvergne, CNRS, IRD, OPGC, F-63000 ClermontFerrand, France; V.Bosse@opgp.univ-bpclermont.fr

(2) Institut für Geologie, Universität Bern, Baltzerstrasse 3, 3012 Bern, Switzerland; Centro Universitario

Datazioni e Archeometria, Università di Milano Bicocca, pza della Scienza 4, 20126 Milano, Italy negligibly small relative to retrograde reaction rates. Multi-element maps demonstrate that patchy textures tightly correspond to $(\mathrm{U}+\mathrm{Th})-\mathrm{Pb}$ age variations, requiring that fluid-induced dissolution/ reprecipitation is the principal cause of $\mathrm{Pb}$ mobility. Attempts to model intracrystalline core-rim $\mathrm{Pb}$ zonations as diffusive transport are not legitimate unless genuine bell-shaped diffusion profiles in minerals can be documented, which happens only exceptionally. Monazite and zircon intra-grain age maps confirm that coupled dissolution-reprecipitation and retrogression reactions assisted by fluids control $(\mathrm{Th}+\mathrm{U})-\mathrm{Pb}$ ages, not temperature. The chemical zonations observed in many $(\mathrm{Th}+\mathrm{U})$-bearing mineral chronometers (e.g. monazite, allanite, xenotime, zircon) provide petrological constraints. Linking petrology with textures and the isotope record allows reconstructing entire segments of the $P-T-A-X-D-t$ history of a rock and its geodynamic environment.

The dearth of mathematically sound diffusion profiles equally applies to the isotope record of micas and feldspars. The tight link between petrology, microtextures, chemical composition and geochronology also pertains to Rb-Sr and K-Ar. Overdetermined multi-mineral Rb-Sr isochrons with excess scatter, and spatially resolved/stepwise release ${ }^{39} \mathrm{Ar}-{ }^{40} \mathrm{Ar}$ results, demonstrate ubiquitous correspondence between relict phases and isotopic inheritance. Many rock-forming minerals are highly retentive of Sr and Ar, unless they are obliterated by retrograde reactions. The rates of dissolution in fluid-controlled reactions are several orders of magnitude faster at upper and mid-crustal levels than diffusive reequilibration rates. Thus, as a rule $\mathrm{Rb}-\mathrm{Sr}$ and $\mathrm{K}-\mathrm{Ar}$ chronometers date their own formation.

Accurately establishing $P-T$ paths of monometamorphic rocks requires assessing petrologic equilibrium using multivariate thermodynamic software. Dating complex parageneses of polymetamorphic, unequilibrated rocks requires labor-intensive disentangling by: (i) qualitative identification of relicts, retrogression reactions, and chemically open systems by imaging techniques (e.g. cathodoluminescence, element maps, etc.); (ii) microchemical analyses at the $\mu \mathrm{m}$-scale quantifying heterochemical disequilibrium phases and assigning them to a $P-T-A-X$ segment; (iii) spatially resolved/stepwise release, relating the chemical signature of the analyzed mineral to its age. $\mathrm{K}-\mathrm{Ar}$ and $\mathrm{Rb}$-Sr usually provide a different perspective on the $P$ - $T$ evolution of a rock than does $(\mathrm{Th}+\mathrm{U})-\mathrm{Pb}$, as $\mathrm{K}+\mathrm{Rb}$-rich minerals (phyllosilicates and especially feldspars) mostly form later and react/dissolve faster in the retrograde path than U-rich accessory phases (e.g. Mukaiet al., 2014). The present 
paper reviews these general principles by means of well-understood examples, both successful and insuccessful in matching the independently known external constraints.

\section{Introduction}

Geodynamic models of the lithosphere seek to reconstruct the tectonic evolution and its duration. To this end, it is very useful to be able to link the information provided by microstructures to the petrogenesis of that same rock, and to connect both to the time information, to constrain the rates of crustal processes (Vance et al., 2003). The discipline connecting petrology and geochronology was later termed petrochronology (KylanderClark et al., 2013). Most metamorphic rocks record not just an instantaneous formation but a plurality of mineral-forming events, such that polymetamorphic and polycyclic rocks predominate in Pre-Cenozoic terrains. When studying Precambrian tectonics, field relations are often obscured by subsequent deformation, and petrological relations are often obscured by multiple metamorphic overprints. This makes tectonic models of Precambrian terrains especially vulnerable to the complexities of mineral geochronometers. The observation of relict minerals with abrupt compositional zonations, and in general of petrologic disequilibrium, poses a fundamental interpretive difficulty: assigning an age to each mineral generation, and linking each generation to the tectonic event that created the metamorphic conditions that led to its growth. Getting analytical data has become apparently easy. It is therefore important to improve the way that a mass spectrometric number is converted into a geological history and geodynamic context. This requires clarifying the approach used to interpret the geochronological data in order to increase the accuracy and reliability of tectonic models based on them.

A mineral is a useful petrochronometer if it fulfills two conditions: (1) its composition must be variable, in such a way that it records variable $P-T-A-X-D$ (pressure-temperature-water activity-compositiondeformation) conditions and allows tracing of chemically open-system behaviour; (2) its petrologic signature and its chronometry must be set simultaneously in the same geological event and remain unmodified ever since. When both conditions are fulfilled, it becomes possible to link the petrological and structural evolution of the chronometer to that of the rock, then on a larger scale to that of the geological unit, and finally to that of the orogenic belt.

The present review will discuss the kind of tectonic information that can be gained from geochronological data. To do so, it will address the fundamental assumptions underlying petrochronology by discussing examples of $(\mathrm{Th}+\mathrm{U})-\mathrm{Pb}$ dating in monazite and $\mathrm{K}-\mathrm{Ar}$ dating in micas in various tectonometamorphic contexts. The studied examples show that (i) fluid assisted dissolution-precipitation processes rather than temperature-dependent solid diffusion predominantly govern the closure of the $(\mathrm{Th}+\mathrm{U})-\mathrm{Pb}$ system; (ii) monazite is particularly sensitive to the interaction with fluids of specific composition $\left(\mathrm{F}, \mathrm{CO}_{2}, \mathrm{~K} \ldots\right)$, even at low temperature; (iii) in the absence of fluids, monazite is able to record HT events and to retain this information during (poly-)metamorphism and even partial melting; (iv) patchy chemical and isotopic zonations, well known in monazite, reflect the fluid-assisted interaction with the surrounding mineral assemblages. 
$\mathrm{K}-\mathrm{Ar}$ chronometer minerals show similar patterns of isotopic inheritance closely tied to relict patches and heterochemical retrogression phases (Villa and Williams 2013). Isotopic closure in both ( $\mathrm{U}+\mathrm{Th})-\mathrm{Pb}$ and $\mathrm{K}-\mathrm{Ar}$ systems follows the same principle: thermal diffusion is very slow, dissolution and reprecipitation are several orders of magnitude faster under typical crustal conditions. This means that both ( $\mathrm{Th}+\mathrm{U})-\mathrm{Pb}$ and $\mathrm{K}-\mathrm{Ar}$ mineral chronometers are hygrochronometers. The petrochronological interpretation of the ages of the different domains cannot be decoupled from the geochemical and petrological context.

One crucial criterium for petrochronology are the relative rates of mineral-forming reactions and of diffusive reequilibration. A mineral that preserves both its major element composition and its radiogenic isotope signature has a petrogenetic stability field that allows its growth at temperatures lower than its "closure temperature" for diffusive loss of radiogenic isotopes as defined by Dodson (1973). Mineral petrochronometers all have this property (they were called "Class II chronometers" by Villa, 2016). In contrast, "Class I chronometers" (also called thermochronometers) are minerals that are open to diffusive loss of one or more daughter isotopes whenever they are formed, and only become closed to diffusive loss at a lower $T$ than that at which they were formed.

The focus on petrology also implies, following Villa $(1998,2016)$, that the ages measured in petrochronometers from metamorphic rocks do not exclusively conform, in a mathematically invertible way, to the "closure temperature" concept (Dodson 1973). Examples of geodynamic models that only focus on the $\mathrm{km}$-to-Mm scale and fail to take into account the atomic scale processes will also be discussed below. The only way forward is to bridge the gap between (sub-) $\mu \mathrm{m}$-scale processes well understood by petrologists and mineralogists and km-scale processes addressed by tectonic models.

\section{$(\mathrm{Th}+\mathrm{U})-\mathrm{Pb}$ petrochronometry}

Most $\mathrm{Th} \pm \mathrm{U}$-bearing minerals have high field strength elements (HFSE) as major cations, and inherently fulfill the requirement of efficient resistance to retrogradation and consequent degradation of the $P$ $T-A-X$ information. One such mineral is monazite (Th, $\mathrm{U}, \mathrm{Ca}, \mathrm{Y}, \mathrm{Si}, \mathrm{LREEPO}_{4}$ ), an accessory mineral in magmatic (mainly peraluminous and carbonatitic) and metamorphic rocks (mainly Ca-poor and Al-rich metapelites) where it represents one of the major reservoirs of lanthanides and actinides in the continental crust (Bea et al. 1996). Because of its wide range of possible cation substitution, monazite is a good tracer of the petrological events. Changes in the concentrations of Y, REE, Th, U reflect the partition of these elements between monazite and other minerals of the paragenesis that was in equilibrium at the time of monazite growth. Thermodynamic modelling allows to place monazite in a $P-T-A-X$ grid (Mottram et al. 2014; Didier et al. 2015). However, integrating monazite in phase relations models and thermodynamic calculations is complex, because thermodynamic models remain highly dependent on the precise measurement of the trace elements in all the associated silicates.

Its high Th content ( $\mathrm{ThO}_{2}$ up to $15 \mathrm{wt} \%$ and more), and to a lesser extent $\mathrm{U}\left(\mathrm{UO}_{2}\right.$ content $\left.<2 \mathrm{wt} \%\right)$, 113 allows the simultaneous use of three isotopic ratios (in order of abundance: ${ }^{208} \mathrm{~Pb} /{ }^{232} \mathrm{Th},{ }^{206} \mathrm{~Pb} /{ }^{238} \mathrm{U}$, and ${ }^{207} \mathrm{~Pb}$ 
$\left.114 /{ }^{235} \mathrm{U}\right)$ as independent radiometric clocks that control each other. In young $(<50 \mathrm{Ma})$ and/or U-poor monazite,

$115{ }^{232} \mathrm{Th}-{ }^{208} \mathrm{~Pb}$ ages are preferentially used for two reasons: (i) Th is more abundant than $\mathrm{U}$; (ii) the $\mathrm{U}$ decay series 116 could affected by secular disequilibrium and contain parentless ${ }^{230} \mathrm{Th}$ (Schärer, 1984), resulting in ${ }^{206} \mathrm{~Pb}$ excess 117 and overestimated ${ }^{206} \mathrm{~Pb} /{ }^{238} \mathrm{U}$ ages. Contrary to zircon, monazite is not sensitive to radiation damage (Seydoux118 Guillaume et al., 2002a; Seydoux-Guillaume et al., 2004; Seydoux-Guillaume et al. 2018): despite the high 119 irradiation doses accumulated over long periods due to high Th and $\mathrm{U}$ contents, monazite is not affected by 120 amorphisation over time. Thus, the possibility that radiogenic $\mathrm{Pb}$ (hereafter $\mathrm{Pb}^{*}$ ) is lost by leaching from an 121 amorphous crystalline lattice, and the consequent perturbation of the measured ages, can be usually ruled out. 122 Experimental studies (Cherniak et al. 2004 ; Gardés et al. 2006) have shown that intracrystalline volume 123 diffusion of $\mathrm{Pb}^{2+}$ in pristine monazite is extremely slow in the laboratory (Fig. 1). In lithospheric conditions it 124 is orders of magnitude slower, as natural $\mathrm{Pb}^{*}$ has valence 4+ (Kramers et al., 2009) and therefore has a lower 125 diffusivity (see also below). Thus, neither $\mathrm{Pb}^{*}$ diffusion nor $\mathrm{Pb}^{*}$ loss caused by radiation damage can disturb 126 the ( $\mathrm{Th}+\mathrm{U})-\mathrm{Pb}$ isotope system. Incorporation of initial unradiogenic ("common") $\mathrm{Pb}$ in the crystal structure of 127 monazite was thought to be negligible compared to $\mathrm{Pb}^{*}$ (Parrish, 1990). This has encouraged the development 128 of electron microprobe (EMP) dating, whose underlying assumption is that $\mathrm{Pb}$ is exclusively of radiogenic 129 origin (Montel et al., 1996; Cocherie et al. 1998; Williams et al. 1999; Williams et al. 2011). This is a 130 reasonable assumption in Archean rocks analyzed in these early studies. However, recent experimental 131 (Seydoux-Guillaume et al, 2002b) and natural studies (Janots et al. 2012; Didier et al. 2013) observed 132 incorporation of initial $\mathrm{Pb}$ in monazite. Unradiogenic $\mathrm{Pb}$ is usually not incorporated in the monazite structure 133 but rather concentrated in nanometer-scale $\mathrm{Pb}$-rich clusters as revealed by transmission electronic microscopy 134 and atom-probe imaging (Seydoux-Guillaume et al. 2003; Fougerouse et al. 2018).

135 In addition to the high retentivity of $\mathrm{Pb}^{*}$ at practically all metamorphic temperatures (Cherniak et al. 136 2004; Gardés et al. 2006), monazite has been observed to be very prone to metamorphic recrystallization in the 137 presence of an aqueous fluid (Williams et al. 2007; Villa \& Williams 2013; Williams et al. 2017). This 138 manifests itself as variable chemical compositions at the grain scale and complex compositional zoning 139 usually defining intragrain patches of varied size (Williams et al. 1999; Seydoux-Guillaume et al. 2003) and 140 sharp boundaries (Fig. 2 a, b). Such domains recording changes in physical and chemical parameters are 141 usually connected to specific metamorphic stages recorded by the host rock. When chemical variations are 142 related to isotopic variations, it is then possible to distinguish different stages in the petrological evolution of 143 the host rock and then to its geodynamic history (e.g. Manzotti et al. 2018). Each different, coexisting 144 monazite generations records a point in the $P-T-A-X-D-t$ path of a rock, disentangling its polymetamorphic 145 evolution. The key point, which will be a red thread throughout this paper, is that the diffusive loss of $\mathrm{Pb}^{*}$ 146 from monazite is much slower than that of the major elements of the major minerals that are used to constrain 147 metamorphic $P-T-A-X$ conditions. The chemical composition $X$ is being adjusted, as the structure-forming 148 elements of the metamorphic paragenesis are still mobile, at a time when the retention of radiogenic daughters 149 in monazite has been complete for quite a while. Therefore, monazite is a "Class II chronometer", and dates its 150 own formation. 
Some workers (Steck \& Hunziker 1994; Kohn 2013) have instead used monazite as a thermochronometer. The principal criterion to discriminate the legitimacy of this approach is the selfconsistency of results, i.e. the modelling of a tectonic history that can be supported by geological arguments, independently of any circular argumentation based on isotopic data.

Steck and Hunziker (1994) compiled several dozen monazite and mica age data in a transect across the Central Alps. This is a very well mapped area, in which all the "canonical" calibrations of the "closure temperature" approach (Jäger 1967) were based. Steck and Hunziker (1994, their fig. 12) started from the assumption that all mica ages are "cooling ages". From this assumption, a chain of correctly applied logical implications implied two testable predictions: that the age of orogen-wide metamorphism was $38 \mathrm{Ma}$ (the socalled "Lepontine metamorphism"), and that the "closure temperature" of monazite for $\mathrm{Pb}$ loss was $450{ }^{\circ} \mathrm{C}$. The key argument for the latter estimate was the ubiquitous finding that $t_{\mathrm{B}}<t_{\mathrm{M}}<t_{\mathrm{W}}, t_{\mathrm{B}}$ being the biotite $\mathrm{K}-\mathrm{Ar}$ age, $t_{\mathrm{M}}$ the monazite $\mathrm{U}-\mathrm{Pb}$ age and $t_{\mathrm{W}}$ the muscovite-whole rock $\mathrm{Rb}$-Sr age (Fig. 3a). As monazite ages were younger than $38 \mathrm{Ma}$, their argument was apparently rounded off. However, the subsequent direct determination of $\mathrm{Pb}$ diffusivity in monazite (Cherniak et al., 2004; Gardés et al., 2006) established that monazite retains all of its radiogenic $\mathrm{Pb}^{*}$ below $800{ }^{\circ} \mathrm{C}$. This meant that all monazite ages in the Central Alps date the (diachronous) peak metamorphism, whose peak $T$ did not exceed $650{ }^{\circ} \mathrm{C}$, to the interval $15-25 \mathrm{Ma}$ (Fig. 3b). The chain of arguments ought to be reversed: since $t_{\mathrm{W}}$ dates the metamorphic peak, any age higher than $t_{\mathrm{W}}$ contains a component of isotopic inheritance and must not be viewed as a "cooling age", negating the validity of the starting assumption. Inheritance affects most muscovite ages and a few biotite ages in an irregular geographic distribution, sometimes varying in the same locality (Arnold and Jäger 1965). The next implication is thus that retention of radiogenic ${ }^{87} \mathrm{Sr}$ and ${ }^{40} \mathrm{Ar}$ (hereafter ${ }^{87} \mathrm{Sr}^{*}$ and ${ }^{40} \mathrm{Ar} *$ ) in relict micas can occur at $600{ }^{\circ} \mathrm{C}$. This has a further corollary: as the thermal retentivity of micas is high, it is necessary to explain the rejuvenation of some (but not all) micas in the same, low thermal conditions by the predominance of a local, sample-dependent process: fluid-assisted recrystallization instead of temperature-controlled diffusion. Indeed, subsequent studies (e.g. Tartèse et al., 2011) document a tight parallelism between monazite and white mica ages, which can only be explained by interaction with aqueous fluids (see below).

The large-scale tectonic implications are a complete negation of the conclusions by Steck and Hunziker (1994). The metamorphic peak was not synchronous but diachronous in the different units. The relative movement of the units that are now juxtaposed in outcrop in the Central Alps persisted until later than $15 \mathrm{Ma}$. The average exhumation rate from peak pressure to outcrop is doubled. The cause for such a massive misinterpretation of Alpine tectonics was the assumption that monazite and micas were ideal thermochronometers. The assumed "closure temperature" of micas was (unrealistically) low, as in their samples it reflects not diffusion in a chemically closed environment but instead resetting by fluids at very low temperature. One extreme example of dating "white mica" in a petrologically careless/careful way is given by the muscovite-sericite reaction described by Maineri et al. (2003). These workers observed that white mica in 
a related rock suite could come in two varieties: magmatic muscovite, aged $8.5 \mathrm{Ma}$; and sericite, reset at $7 \mathrm{Ma}$

191 at a well-constrained temperature of $230{ }^{\circ} \mathrm{C}$. If they had extrapolated the latter $\mathrm{T}$ - $\mathrm{t}$ point as a

192 "thermochronological anchor point" of general validity for all white micas, regardless of their petrological 193 origin, they would have estimated a "closure temperature" for white mica similar to, but slightly lower than, 194 that proposed by Jäger (1967). Instead, by paying attention to the mineralogical reactions involving an 195 aqueous fluid they were able to infer the correct sequence of events for Elba Island. In summary, the incorrect 196 assumption that all mineral ages can be inverted to constrain a point in T-t space is bound to give incorrect tectonic reconstructions and unsubstantiated models of orogenic processes.

The discussion of the preceding example raises the question which, if any, mineral is a reliable thermochronometer, i.e. one in which the age is always controlled exclusively by diffusion, in such a way that age is always an invertible function of temperature. Diffusion is a very slow process, whose importance in natural rocks has been vastly overrated in the past (cf. the discussion by Villa and Hanchar, 2017, and the many references therein). The requirement stated in the Introduction, that the $P-T-A-X$ signature and the isotopic age of a mineral should pertain to the same geological event, amounts to requiring that the diffusivity of the major elements (those on which the thermobarometry is based) must not be smaller than that of the radiogenic isotope that defines the age.

The mathematical equations for Fick's Law diffusion have a very simple outcome: diffusion always and only produces a bell-shaped (so-called error function, or erf) spatial concentration profile of the diffusant. If a genuine erf profile is observed, then probably Fickian diffusion was the predominant physical phenomenon in that sample (within the uncertainty of the fit of the data to the erf profile). If the spatial distribution of the diffusant resolvably deviates from an erf profile, then Fickian diffusion was not the predominant physical phenomenon, and numerical inversion models that assume Fickian diffusion are inaccurate and illegitimate.

The prime tool for the assessment of core-rim gradients in natural samples is by in-situ dating. In principle, in-situ techniques allow dating a mineral in its petrological-microstructural environment. In practice, an essential limit is the spatial resolution of in-situ analyses. There are two strict physical limits to the accuracy of an in-situ analysis. The upper limit of a useful primary beam diameter is given by the necessity to resolve the intergrowths of diachronous mineral generations in a complete way (Villa \& Hanchar 2017, their figure 9). The literature abounds with reports that infer an incorrect age due to the uncorrected mixing of more than one mineral generation. The lower limit of a useful primary beam diameter is given by the necessity to average away the nm-scale recoil of radiogenic daughter nuclides by natural disintegration of the parent nuclide. Such atom-scale phenomena were documented in zircon by Kusiak et al. (2013), Valley et al. (2014) and Whitehouse et al. (2017) and in monazite by Seydoux-Guillaume et al. (2003) and Fougerouse et al. (2018), and result in a local disproportionation of parent and daughter nuclides. An unquestioning, contextless application of a single spot age obtained with $\mathrm{a}<1 \mu \mathrm{m}$ primary beam would cause an incorrect age assignment of an entire orogenic cycle.

Studying older rocks by in-situ analyses has advantages and drawbacks. The advantage is that the number of radiogenic atoms that are required for precise dating is contained in a smaller volume. This allows 
analyses with a higher spatial resolution and thus makes the dating of microstructurally distinct spots less difficult. The drawback is that the time-resolution provided by older rocks is less detailed than that of recent ones. A $1 \%$ age uncertainty on a mid-Archean age, $30 \mathrm{Ma}$, is the duration of the entire Himalayan orogeny. Using in-situ analyses to tell apart events that lie $1 \mathrm{Ma}$ apart is a serious challenge: for old rocks the analytical precision may be insufficient, for young rocks the spatial resolution may be insufficient to target only one generation of the petrochronometer mineral. Moreover, minor isotopes and/or trace elements are frequently below detection limit if the ablated volume is excessively small. This makes chemical fingerprinting of polyphase mixtures and heterochemical intergrowths difficult or impossible.

The disambiguation of mathematically correct erf profiles from generic core-rim zonation, such as e.g. accretion of a discrete heterochemical phase onto a relict core, requires a spatial resolution one or two orders of magnitude better than the length scale of the zonation. Moreover, if one element exhibits a genuine diffusion gradient in a mineral, then all elements whose boundary conditions allow it must exhibit one as well. Since the diffusion length is proportional to $\sqrt{ } D t$, where $D$ is the diffusion constant and $t$ is the duration of the heating event, all diffusing elements from the same mineral grain must necessarily exhibit diffusion length scales that depend on the (well predictable) relative diffusion coefficients.

Neglecting the systematic dependence of diffusivity on charge and radius is not just an academic detail, as it can lead to unrealistic tectonic modelling. As an example, Ewing (2017) used Zr-in-rutile thermometry to determine metamorphic peak temperatures of ca. $850-950{ }^{\circ} \mathrm{C}$ in lower crustal granulites from Corsica (France). They then dated the rutile by U-Pb and assumed that their age, $160 \mathrm{Ma}$, was a "cooling age" corresponding to exhumation of the rutile through the $550-650{ }^{\circ} \mathrm{C}$ isotherm. This was interpreted as evidence of the exhumation of the lower crust during the formation of the first oceanic crust in the Late Jurassic. However, a few independent constraints conflict with this tectonic model. Firstly, the Jurassic evolution of the geotherms in the entire Corsica-Sardinia block is constrained by fission tracks and $\mathrm{U}^{*}$-He ages (Malusà et al. 2016), whereby the oceanic crust was already being thrust over the continent ca. $10 \mathrm{Ma}$ earlier. Secondly, the lower crust had already been exhumed during the Permian; during the Jurassic rifting the thermal perturbation was weak (Malusà et al 2016). The misunderstanding of diffusion systematics by Ewing (2017) was subtle. The Zr-in-rutile thermometer was assumed to reliably record the peak temperature, which means that the $\mathrm{Zr}$ concentration was not modified by diffusive re-equilibration. On the contrary, The ionic radii of $\mathrm{Zr}^{4+}$ (86 pm) and $\mathrm{Pb}^{4+}(91.5 \mathrm{pm})$ predict that $\mathrm{Pb}^{*}$ diffuses much less fast than $\mathrm{Zr}$, i.e., if $\mathrm{Zr}$-in-rutile records a formation temperature then the $\mathrm{U}-\mathrm{Pb}$ age of rutile must a fortiori record a formation age.

A multichronometric assessment of the internal consistency of models that interpret mica ages following thermochronology was recently reported by Airaghi et al. (2018). Biotite and allanite grew synchronously during burial, and both chronometers give mutually concordant ages between 220 and 180 Ma. The chronometric information recorded by both minerals survived metamorphic peak temperatures of c. 580 ${ }^{\circ} \mathrm{C}$. Retrograde muscovite formed around $130 \mathrm{Ma}$ at c. $370-470{ }^{\circ} \mathrm{C}$ (whereby the size mismatch, discussed above, between "small" mineral grains and "large" laser beam prevents reproducible dating of separate muscovite generations: Airaghi et al., 2018, p. 947). Diffusion modelling is unable to reproduce any of these obervations (Airaghi et al., 2018, p. 954), as predicted by Villa (2016, p. 8). What the allanite and mica 
multichronometry really means is that "petrological and microstructural processes prevail over thermally driven diffusion even at high temperatures" (Airaghi et al., 2018, p. 954), which puts new, robust constraints on the Triassic-Jurassic tectonics of the Longmenshan orogen.

In a very recent paper, Kirkland et al. (2018) analyzed compositional and $\mathrm{Pb}$ isotopic profiles in apatite. They concluded that "To apply $\mathrm{Pb}$ diffusion profiles to determine cooling histories, one must not assume but demonstrate that thermally activated volume diffusion is justifiable because our results show that apatite generally may not record simple thermally activated $\mathrm{Pb}$ diffusion profiles but rather profiles modified in part or whole by recrystallization or new growth" (Kirkland et al., 2018, p. 155).

As evidenced by the three just cited 2017-2018 papers, observations of erf profiles in natural geological systems are very rare (confirming the references cited by Villa 2016). More frequent are the observations of "slow" diffusion being overtaken by superimposed faster processes, such as dissolution/reprecipitation in aqueous fluids (e.g. Labotka et al. 2004, their Fig. 4). The relative magnitude of the rate constants of diffusion and of dissolution also affects very heavily the literature estimates of the geochronology of micas and feldspars. The discussion by Villa (2016) needs not be repeated here; the observation most relevant for the present discussion is that, in the absence of dissolution/reprecipitation due to aqueous fluids, the "dry" diffusivity of the radiogenic daughters in micas $\left({ }^{40} \mathrm{Ar}^{*}\right.$ and $\left.{ }^{87} \mathrm{Sr}^{*}\right)$ is sufficiently low to make these minerals Class II geochronometers.

\section{Beyond (Th+U)-Pb: Rb-Sr and K-Ar}

The reasons why micas are petrochronometers in the $\mathrm{Rb}-\mathrm{Sr}$ and $\mathrm{K}-\mathrm{Ar}$ systems must be sought at the atomic scale. Ar is a very large atom (its van der Waals radius $r_{\mathrm{Ar}}=188 \mathrm{pm}$, much larger than oxygen and the structure-forming cations) with a high polarizability. It does not form true bonds but can be adsorbed onto a surface by van der Waals forces, with an activation energy around $10 \mathrm{~kJ} / \mathrm{mol} . \mathrm{Sr}^{2+}$ is even larger and less adapted to to the silicate framework (its covalent radius $r_{\mathrm{Sr} 2+}=195 \mathrm{pm}$ ). $\mathrm{Pb}^{4+}$ is also very large, and due to its high charge (Kramers et al. 2009) it is one of the slowest diffusants. Definitely a single Ar atom is not a "noble gas" in the thermodynamic sense. The properties of a gas are manifested when there are a few millions other free gas atoms, all of whom obey the equations of statistical mechanics. On the other hand, when an individual Ar atom is trapped intersitially within a solid as a single atom it is so impeded in its movement that Boltzmann's Law $[v \sim \sqrt{ }(\mathrm{k} T)]$ does not apply. The threshold for gaseous behaviour is reached when the mean free path of the atoms at the $T$ of interest is smaller that the size of the cavity it is confined in. This corresponds to a few hundred $\mathrm{nm}$ inclusions (depending on the entrapment $P$ and $T$ ). When the inclusion's internal overpressure, given by $P=n \mathrm{R} T / V$, exceeds the strength of the solid host, can the trapped atoms be released as a gas by decrepitation. Just as evidently, an Ar atom trapped in a solid is not a Fickian diffusant. After decades of confusion, it has become clear that the measured activation energies for Ar transport provide unambiguous constraints on where, how and why an Ar atom can migrate. Ar makes no bonds with structure-forming cations, nor with 
oxygen, and thus should have a partition coefficient near zero. Other than in (passively trapped) fluid inclusions, ${ }^{40} \mathrm{Ar}$ never comes into a crystal except as the radiogenic daughter, ${ }^{40} \mathrm{Ar}$, of a ${ }^{40} \mathrm{~K}$ atom that captured one of its $1 \mathrm{~s}$ electrons. When the excited ${ }^{40} \mathrm{Ar} *$ isomer decays to the ground state, it emits a gamma photon with an energy of $1.46 \mathrm{MeV}$. By momentum conservation, the ${ }^{40} \mathrm{Ar} *$ nucleus recoils by tens of $\mathrm{nm}$, during which movement it probably also undergoes recoil stripping of a few of its electrons. Thus, the ${ }^{40} \mathrm{Ar}^{*}$ ion is no longer located in the same crystallographic location as its parent isotope ${ }^{40} \mathrm{~K}$. Its positively charged state is metastable and the electrical neutrality might be recovered quickly, but no experimental data exist so far.

312 A further argument against the free mobility of rare gases through the mineral structure is the very different

313 diffusivity and activation energy of Ar and Xe. Hetherington and Villa (2007) measured the degassing rate of 314 irradiated celsian, in which neutron-produced ${ }^{39} \mathrm{Ar}$ and ${ }^{131} \mathrm{Xe}$ were measured simultaneously. If both had been 315 free to move, both should exhibit similar activation energies, of the order of the van der Waals binding energy. Instead, the observed activation energy of Ar in celsian was $180 \mathrm{~kJ} / \mathrm{mol}$, similar to that of alkali diffusion, whereas the observed activation energy of Xe was $330 \mathrm{~kJ} / \mathrm{mol}$, similar to that of Ba diffusion.

318 The energy budget of Ar migration in natural solids is extremely difficult to measure. Mineral chronometers 319 relevant for the K-Ar system are mostly hydrous (amphiboles, micas), feldspars being the anhydrous mineral 320 most widely used as a chronometer. At this time, the reliable estimates of Ar diffusivity in natural mineral 321 chronometers can be counted on the thumbs of one hand. Experiments on hydrous minerals return the 322 dissolution/reprecipitation rate (Villa, 2010, 2016) instead of the Fick's Law diffusivity. Experiments on feldspars (Wartho et al., 1999) can return a true diffusivity only provided the sample is ideally monomineralic. Polymineralic samples return average properties of the sum of all coexisting phases (Chafe et al., 2014). Despite the general unreliability of literature estimates for Ar diffusivity, a few guidelines can orient users through the apparent disorder of the database: (i) diffusion occurs always, but is always the slowest transport mechanism (Villa, 2016; Villa and Hanchar, 2017 and references therein); (ii) the similarity of activation energies for dissimilar diffusants is proof that the limiting factor in diffusion are the properties of the matrix structure, in particular the creation of Schottky vacancies that allow the movement of cations across the structure; (iii) the vast variations in frequency factors, i.e. of the likelihood that a given ion will exploit the newly created Schottky vacancy, are a function of charge and radius of the diffusant: larger ions have lower frequency factors (Chakraborty and Ganguly, 1992), as do ions with a higher charge (Cherniak 2006, 2010).

334 The Rb-Sr ages reported in the references quoted by Steck and Hunziker (1994) are affected by an additional problem besides the relative role of diffusion and recrystallization. The cited mica Rb-Srages were all twopoint mica-whole rock isochrons. Two-point isochrons may assign a not entirely incorrect general geological era, but their accuracy relies on the isotopic equilibrium between the two analyzed data points. In the case of a metamorphic system, the whole rock always contains relict phases and retrogression products, which guarantees an incomplete isotopic equilibrium and a questionable accuracy of isochrons. When metamorphic rocks are dated by $\mathrm{Rb}-\mathrm{Sr}$ it is necessary to obtain overdetermined internal isochrons by analyzing a large number of coexisting minerals. The cogeneticity manifests itself by a low dispersion of the data points, 
whereas rocks showing disequilibrium between relict phases and retrograde minerals also show higher dispersion (e.g. Glodny et al., 2008, their Fig. 5).

344 Reliable laboratory determinations of diffusivity for $\mathrm{K}-\mathrm{Ar}$ and $\mathrm{Rb}-\mathrm{Sr}$ mineral geochronometers are very rare (Villa 2016). Practically there is only one mineral, K-feldspar, for which both $\mathrm{Sr}$ and Ar diffusion have been determined directly by depth profiling (Ar: Wartho et al. 1999; Sr: Cherniak and Watson 1992). The comparison of the two data-sets shows that both diffusants have a nearly identical activation energy (see above for the physical reasons for this near-identity). However, diffusivities are not equal, as the frequency factor for Ar diffusion is $4 \times 10^{-4}$ times larger than that for $\mathrm{Sr}$, following the systematic prediction based on charge and radius. This predicts a large age difference between $\mathrm{Rb}-\mathrm{Sr}$ and $\mathrm{K}-\mathrm{Ar}$ ages in purely diffusive alkali-rich thermochronometer minerals. Whenever concordant $\mathrm{Rb}-\mathrm{Sr}$ and $\mathrm{K}-\mathrm{Ar}$ ages on the same mineral are observed instead, then diffusion was subordinate to recrystallization, which accelerated (at least) the diffusion of Sr by (at least) a factor 40000 .

\subsection{Example 2. Mica petrochronometry}

As mentioned in the introduction, petrochronometers are minerals that allow the estimate of $P-T-A-X-d$ and simultaneously of $t$. Some minerals, such as e.g. diamond, conveniently shield inclusions from retrogression; this makes them very indirect thermobarometers, and even if diamond can be successfully dated (Burgess et al. 2002), defining diamond a petrochronometer seems questionable.

More frequently occurring mineral petrochronometers are micas. In a classic Lepontine locality in the Central Alps, Allaz et al. (2011) studied the $P-T-A-X$ evolution by multivariate thermobarometry. From their data it is possible to reconstruct an entire segment of the P-T-t path (Fig. 4). The metamorphic peak at ca. 18-19 Ma $\left(840 \pm 50 \mathrm{MPa}, 594 \pm 14{ }^{\circ} \mathrm{C}\right)$ is dated by monazite U-Pb ages (Janots et al., 2009). One muscovite, AMo0410, gives a ${ }^{39} \mathrm{Ar}-{ }^{40} \mathrm{Ar}$ age of $18.9 \pm 0.8 \mathrm{Ma}$, indistinguishable from the monazite ages. Muscovite of a sample collected $<0.5 \mathrm{~km}$ to the North, AMo0409, grew at lower-grade conditions $\left(660 \pm 20 \mathrm{MPa}, 573 \pm 11^{\circ} \mathrm{C}\right)$ at a slightly later time, $17.9 \pm 0.6 \mathrm{Ma}$. The assemblage of AMo0410 records crossing the paragonite-out boundary, which almost completely consumed the first paragonite generation, Prg-1. The rock was exhumed and cooled, thereby re-entering the paragonite stability field at $P=380 \pm 20 \mathrm{MPa}, T=480 \pm 20^{\circ} \mathrm{C}$. This caused the growth of a texturally clearly distinct Prg-2 generation, whose ${ }^{39} \mathrm{Ar}-{ }^{40} \mathrm{Ar}$ age, $13.3 \pm 2.3 \mathrm{Ma}$, dates the crossing of the paragonite-in boundary. In contrast, paragonite of sample ALu0603, $5 \mathrm{~km} \mathrm{NNW}$ of the two AMo samples, was not destabilized and its ${ }^{39} \mathrm{Ar}-{ }^{40} \mathrm{Ar}$ age coincides with the muscovite age. From the white mica ages of AMo0410 it is possible to derive an average cooling and exhumation rate between $18.9 \pm 0.8$ and $13.3 \pm 2.3 \mathrm{Ma}$. The exhumation by $460 \pm 27 \mathrm{MPa}$ in $5.6 \pm 2.5 \mathrm{Ma}$ corresponds to roughly $3 \mathrm{~mm} / \mathrm{a}$. The cooling by ca. $114 \pm 13{ }^{\circ} \mathrm{C}$ in the same interval gives a cooling rate of $20 \pm 9{ }^{\circ} \mathrm{C} / \mathrm{Ma}$. In addition to the direct dating of the $P-T$ segment between $840 \mathrm{MPa}$ and $380 \mathrm{MPa}$, micas in sample AMo410 provided an additional bonus. The identical ${ }^{39} \mathrm{Ar}-{ }^{40} \mathrm{Ar}$ ages of $16.3 \pm 0.4$ Ma obtained on the two biotite samples AMo0409 and AMo0410 are younger than muscovite growth. Both biotite samples record the sum of two processes: genuine diffusion, and chloritization. The two have not been disentangled in this case. It is very 
doubtful that there exist $100 \%$ retrogression-free biotites on Earth, as even prime museum specimens display microchemical evidence of violation of stoichiometry, attributed to secondary interaction with fluids (Naumenko-Dèzes et al. 2018). In any case, assuming (purely for the argument's sake) that chloritized biotite AMo0410 was not chloritized but only lost Ar by diffusion, then the biotite ages are cooling ages. By interpolating between the muscovite growth at $18.9 \pm 0.8 \mathrm{Ma}$ and the Prg-2 growth at $13.3 \pm 2.3 \mathrm{Ma}$, the biotite ages correspond to a temperature of $542 \pm 33{ }^{\circ} \mathrm{C}$. A note of caution is that the retention of Ar by biotite below $550{ }^{\circ} \mathrm{C}$ cannot be uncritically extrapolated to all biotites of this planet. It only pertains to moderately retrogressed, undeformed minerals, whose petrologic equilibrium has previously been assessed. As dissolution by aqueous fluids is several orders of magnitude faster than thermally activated volume diffusion (Villa 2016, his Fig. 1), even minute traces of water circulation can effect recrystallization at virtually all temperatures. In the absence of a complete $P-T-A-X$ characterization of the entire paragenesis, extrapolation of any "closure temperature" for any Class II mineral is not legitimate. An example of the opposite legitimacies of mica thermochronometry and mica petrochronology is the traverse across the Western Alps studied by Villa et al. (2014). These authors observed that in the westernmost part of the traverse white mica underwent major rejuvenation at ambient temperatures $<300{ }^{\circ} \mathrm{C}$, whereas in the easternmost part white mica retained part of its inherited ${ }^{40} \mathrm{Ar} *$ during, and all of its ${ }^{40} \mathrm{Ar} *$ after, the eclogitic peak at $T \approx 600-630{ }^{\circ} \mathrm{C}$. This contrasting behaviour is clearly incompatible with one good-for-all "closure temperature" (Fig. 5a). What petrology shows instead is that detrital muscovite in the low-grade, water-rich sediments of the western part was progressively recrystallized to phengite. The coupled eastward increase of pressure and deformation effected an increase of the Si substitution in phengite and a correlated rejuvenation. Once all protolith muscovite was converted to phengite, a further eastward temperature increase had no rejuvenating effect on phengite ages, which stayed constant and concordant with the Lu-Hf garnet ages (Fig. $5 b)$.

Older literature based on white mica thermochronology attributed eclogitization to the Middle Cretaceous, implying subduction of the Liguro-Piemontese Ocean shortly after its Late Jurassic opening, followed $100 \mathrm{Ma}$ later by a separate greenschist overprint. Instead, mica petrochronology established that eclogitization was Eocene, rapidly followed (within 8-10 Ma) by greenschist retrogression along the same exhumation path, making the entire subduction-collision event both younger (by ca. $80 \mathrm{Ma}$ ) and more rapid. A potential complication, isotopic inheritance, can be diagnosed both a priori and a posteriori, as it is closely tied to relict patches and heterochemical retrogression phases (Villa and Williams 2013). In this particular locality it had been avoided by choosing monometamorphic metasediments. When dealing with polymetamorphic rocks, sample selection for petrochronology must be preceded by a very extensive 
In metamorphic reactions, fluid-assisted processes are not the exception, but rather the rule (Putnis

418 2002, 2009; Putnis and John 2010). Fluids play a catalytic role by decreasing the activation energy of a 419 reaction and by promoting the dissolution/precipitation processes and material transport. Even at HT conditions in eclogite and granulite conditions, Putnis and Austrheim (2013) showed that the availability of fluids is an essential condition for the metamorphic reactions to proceed, whereas solid-state reactions only involving volume diffusion are not the dominant mechanism (see also Mukai et al., 2014; Centrella et al., 2016). Finally, these authors question the difference between metasomatism and metamorphism and conclude that there is no fundamental difference between the two processes at the molecular scale: metamorphism involves fluids, albeit at local scale and lower volume. Thus, dating the fluid circulation events associated with the formation of a metamorphic paragenesis requires the use of hygrochronometers.

Monazite is well known for its high reactivity in presence of fluids even at low temperatures (Poitrasson et al. 1996; Teufel and Heinrich 1997; Townsend et al. 2001; Seydoux-Guillaume et al. 2002; Bosse et al. 2009; Harlov and Hetherington 2010; Hetherington et al. 2010; Harlov and Hetherington 2011; Williams et al. 2011; Budzyn et al. 2011; Didier et al. 2013): the dissolution/recrystallization processes ubiquitously observed in metamorphic rocks induce the formation of intra-grain monazite domains of distinct age and chemistry, whatever the thermal conditions. Monazite should therefore be called a hygrochronometer.

433 In fluid-assisted dissolution-precipitation processes, precipitation is usually spatially associated with 434 dissolution along the dissolved interface (Putnis 2002). The newly formed monazite usually crystallizes as a more or less discontinuous overgrowth surrounding the primary crystal (see for example Fig. 8 and 9). This is the result of the often restricted mobility of the monazite major elements and induce porosity development, total or partial preservation of the initial grain shape (pseudomorph) and mixing between successive monazite generations at small scale ( $<500 \mathrm{~nm}$ ) (Fig. 6; Grand'Homme et al. 2016). This highlights the heterogeneous character of the monazite at the nanoscale observed by atom probe and TEM imaging (Fougerouse et al. 2018; Grand'Homme et al. 2018), and at the same time confirms the negligibility of diffusive reequilibration. Monazite reactivity mainly depends on the $A-X$ of the interacting fluid rather than $P-T$ conditions (SeydouxGuillaume et al., 2002 ; Teufel and Heinrich,1997; Hetherington et al., 2010). Experimental studies show that fluids rich in $\mathrm{F}, \mathrm{CO}_{2}, \mathrm{Ca}$, and alkali strongly influence the stability of monazite (Hetherington et al., 2010, Harlov and Hetherington, 2010; Harlov and Hetherington, 2011, Budzyń et al., 2011, Richard et al., 2015) and the mobility of $\mathrm{Th}, \mathrm{U}$ and $\mathrm{Pb}$. Didier et al. (2013) report $\mathrm{Th} / \mathrm{U}$ fractionation during hydrothermal processes in presence of F-rich fluids with attending age disturbances. Both $\mathrm{Th}$ and unradiogenic $\mathrm{Pb}$ were independently enriched in variable proportions in the hydrothermal monazite (Fig. 7). This led, in the case studied, to meaningless ${ }^{208} \mathrm{~Pb} /{ }^{232} \mathrm{Th}$ ages, some becoming older by the effect of excess $\mathrm{Pb}$, and some younger by late-stage incorporation of $\mathrm{Th}$. As the $\mathrm{U}$ content remained nearly constant, the ${ }^{206} \mathrm{~Pb} /{ }^{238} \mathrm{U}$ ratio also scatters, due to external $\mathrm{Pb}$ incorporation. A similar behavior has been described with various fluid compostion by Janots et al. (2012), Wawrzenitz et al. (2012) and Grand'Homme et al. (2018).

During metamorphic reactions, the fluid composition is mainly controlled by local equilibria and depends on the reactivity of the other major and trace minerals involved in the reactions. Because fluid composition also strongly controls the behavior of the monazite during dissolution/recrystallization processes, 
it is not possible to predict a priori in which direction the $\mathrm{Y}, \mathrm{REE}, \mathrm{Th}, \mathrm{U}$ or $\mathrm{Pb}$ content will change. Thus low or high-Y or Th content in monazite domains cannot be used a priori as tracers of specific metamorphic conditions (as proposed by Kohn, 2016) in order to attribute ages measured in the same domain to specific metamorphic stages. $P-T-A-X$ conditions must instead be calibrated independently for each metamorphic reaction on a case-by-case basis, using the compositions of monazite and of other reactants. With such extensive work, the monazite can be used as a powerful tracer of the tectono-metamorphic events. The recrystallized domains synchronously record the age and the $A-X$ conditions at the time of their formation. This allows precise dating of tectonic or metamorphic, successive or polycyclic events. The following examples illustrate the effectiveness of the monazite hygrochonomometer for that purpose.

\section{Example 3. Dating deformation}

metamorphic rocks remains a challenge (Williams and Jercinovic, 2002; Wawrzenitz et al. 2012; Dumond et al. 2013; Erickson et al. 2015). Dating of-deformation first requires a geochronometer mineral showing microstructural evidence of (re)crystallization following the. Secondly, the chemical composition of the geochronometer must reflect the metamorphic conditions aking place during deformation, taking care to recognize and exclude relict grains or inherited subgrains having crystallized before the deformation event. Last but not least, there is the difficulty of resolving the ages of events that are close in time. The didactically illuminating examples provided by Williams et al. (2011) pertain to the discrete Proterozoic overprint of an Archean rock in the Athabasca granulite terrain (Canada) in a separate orogeny. The next challenge is now constraining the petro-hygrochronological sequence of the prograde and retrograde $P-T-A-X-D-t$ segments of a single orogenic cycle in the Meso-Cenozoic as an actualistic tool to better understand Precambrian orogenies.

Didier et al. (2014) observed deformation textures in monazite grains and dated the deformation events by coupling monazite geochronology with a detailed petrological and structural study. This study focuses on garnet-kyanite (Grt-Ky) metapelites embedded within two major shear zones of the central part of the Rhodope Metamorphic Complex (Greece, Bulgaria) : the Nestos shear zone (NSZ) in Grece and the Chepelare shear zone (CSZ) in Bulgaria. Samples from both locations have experienced two stages of high temperature metamorphism during Alpine times. The first event involved mid-Mesozoic upper amphibolite - granulite facies «dry» melting. The second event involved mid-Cenozoic lower amphibolite fluid-assisted partial melting. All samples, despite some petrological differences, show microstructural evidence for strong ductile shearing in the presence of fluids. Monazite is abundant as inclusions in garnet and kyanite and in the highly foliated matrix. The matrix grains show strong evidence that at least part of their growth occurred during deformation: i) crystallization channeled along muscovite cleavages (Fig. 8a and e), small satellite grains surrounding larger monazite grains (Fig. 8b), iii) clusters of contiguous small grains possibly replacing an older grain (Fig. 8c) or strings of small monazite grains parallel to the matrix foliation (Fig. 8d). These monazites are commonly associated with rutile (Fig. 8e) and biotite grains which also crystallized along the cleavage planes of the host muscovite (Fig. 8c) or in asymmetric strain shadows around garnets. All these 
textural characteristics of monazite suggest a syn-deformation fluid-assisted monazite growth. Matrix monazite also displays strong chemical and isotopic zoning : the large Y-poor cores yield mid-Mesozoic ages (ca. 115 and $165 \mathrm{Ma}$ ), similar to the monazite inclusions in garnet and kyanite, and the thin, commonly irregular Y-rich rims yield Cenozoic ages (ca. $36 \mathrm{Ma}$ ) (Fig. 9). The small Y-rich monazite grains parallel to the main foliation also display Cenozoic ages. These observations clearly show that new syndeformation monazite generation formed at ca. $36 \mathrm{Ma}$ as the result of fluid-assisted inter-grain mass transfer.

Mesozoic monazite is the main precursor of the new monazite generation. Hence, a process of dynamic dissolution-reprecipitation, as described by Wawrzenitz et al. (2012), probably accounts for the growth of the Cenozoic monazite: the chemical composition of the new grains record the metamorphic conditions of the new environment during deformation, and the shape of the monazite grains indicates the sense of shear, thus linking the measured ages directly to the map-scale tectonic transport. Sharp boundaries separating the chemical domains of distinct ages testify that old monazite grains survive the intense fluidassisted deformation and are totally preserved. Diffusion processes were not effective. Clearly, the record of the deformation age is the result of dissolution-recrystallization processes rather than intracristalline temperature-dependent diffusion of trace elements.

In the Rhodope samples, the recrystallization of monazite occurs at $\mathrm{P} \approx 8-10 \mathrm{kbar}$ and $\mathrm{T} \approx 650{ }^{\circ} \mathrm{C}$. But dissolution - recrystallization of the monazite is also known to be possible at lower grade conditions. In the Variscan Agly massif localized in the North-Pyrenean zone (Eastern Pyrénées, France), Variscan monazite in para- and ortho-gneisses sampled in mylonitic shear zones displays recrystallized domains of Cretaceous age (125-110 Ma) related to the Albian extension between the Iberian and European plates. In these samples, fluidassisted deformation occurs at decreasing temperature conditions from $\mathrm{T}>550^{\circ} \mathrm{C}$ to $\mathrm{T} \approx 200^{\circ} \mathrm{C}$. Younger ages (c. $110 \mathrm{Ma}$ ) are associated with brittle deformation whereas older ages (c. $125 \mathrm{Ma}$ ) are associated with ductile microstructures suggesting a continuous record of the deformation during the cooling and the exhumation of the Agly massif in the Cretaceous times (Aumar, 2018). It is important to note that Cretaceous ages have been only recorded in syn-tectonic minerals such as monazite, titanite ((Th+U)-Pb system) and micas ( $\mathrm{K}-\mathrm{Ar}$ system) (Chelalou et al. 2016; Nicolas, 1998), but not in zircon. Outside the shear zones, Variscan monazites are preserved. These examples again document that fluid-assisted recrystallization during deformation is responsible for the isotopic closure of the ( $\mathrm{U}+\mathrm{Th})-\mathrm{Pb}$ and $\mathrm{K}-\mathrm{Ar}$ systems in minerals that actively participate in metamorphic reactions.

\section{Example 4. Polyclism and polymetamorphism}

Crystalline complexes occasionally feature rocks having experienced polycyclic metamorphism during several successive orogenies and/or other geodynamic settings. Polycyclism needs to be distinguished from continuous successive stages of a $P-T$ path during a single orogenic cycle (Gautier et al. 2017). The possible identification of several stages of deformation or successive metamorphic parageneses may only reflect the complex evolution of a single orogen. Geochronological data may give the best evidence of polycyclism, 
provided that these are closely related to structural and petrological data. In contrast, an erroneous attribution of some ages to structures and/or metamorphic assemblages can lead to a wrong tectonic interpretation. This is especially the case for polycyclism, as specific metamorphic conditions (e.g. eclogitization or migmatization) related to an old orogeny may be attributed to a younger one. However, dating the mineral assemblages corresponding to distinct metamorphic events in the same rock is never easy, especially when $P-T$ conditions of these events are close. This is the case for the Grt-Ky metapelites described above (Didier et al., 2014), for which a detailed petrological study did not allow rigorous identification of two Mesozoic and Cenozoic parageneses. Only matrix monazite was able to record the two successive events, thanks to the presence of fluids during the deformation in Cenozoic times.

Another example of polycyclism recorded by monazite is given by the study of coronitic paragneisses in the Les Essarts high-pressure unit, which occurs in the Southern Armorican Massif (Vendée, Western France). It delineates a NW-SE-trending zone about $70 \mathrm{~km}$ long and a few $\mathrm{km}$ wide, between two lateVariscan dextral faults (e.g., Godard, 2001, 2009). It comprises eclogite and amphibolite derived from eclogite, which form lenses several km long, stretched and boudinaged in ortho- and paragneisses. The host coronitic paragneisses have undergone a complex evolution: high- $\mathrm{T}$ metamorphism $\left(\mathrm{T} \approx 670{ }^{\circ} \mathrm{C}, \mathrm{P} \approx 0.32\right.$ $\mathrm{GPa}$ ) followed by retrogression during Proterozoic times and eclogite-facies overprint $\left(\mathrm{T} \approx 700{ }^{\circ} \mathrm{C}, \mathrm{P} \approx 1.6\right.$ $\mathrm{GPa}$ ) and final retrogression during Variscan times (Godard, 2009). The second episode gave rise to many pseudomorphic and coronitic reactions and caused high-pressure minerals to grow at the expense of the previous high-temperature parageneses. Monazite is highly abundant in the coronitic paragneisses. Some samples show disequilibrium textures with the surrounding matrix minerals. Apatite-bearing coronas around monazite only developed at contacts with plagioclase following the reaction : Mnz1 + Pl (LP - HT) $=$ Mnz2 + $\mathrm{Ap}+\mathrm{Zo}(\mathrm{HP}-\mathrm{LT})($ Fig.10a). This gives us the opportunity to date the different metamorphic events in these samples. Very small chemical differences are observed between the core of the M1 monazite grains (c. 30 to $>100 \mu \mathrm{m}$ in size) and the small M2 monazite grains in the corona $(<5 \mu \mathrm{m}$ in size). This argues in favour of very limited element transport during the reaction and in situ dissolution/reprecipitation processes. Regarding the geochronological data, three different groups of ages can be distinguished. Few data yield concordant Th$\mathrm{U}-\mathrm{Pb}$ ages in the monazite cores at around $590-600 \mathrm{Ma}$, whereas the majority of the measured ages is at around $485 \mathrm{Ma}$ (Fig. 10b; Bosse et al. 2010). The third group corresponds to the M2 monazites in the corona. Because of the small size of the M2 grains relative to the laser spot size $(5 \mu \mathrm{m})$, which induces a variable amount of mixing with the adjacent minerals and unradiogenic $\mathrm{Pb}$ contamination, most of the $\mathrm{M} 2$ analyses are discordant. The few concordant ones are highly scattered. Thus constraining the age of the HP event in these samples was not easy mainly for technical reasons (i.e. the laser spot size) and the results are not very precise, between 400 and $350 \mathrm{Ma}$. The most striking feature here is that, despite the complexity of the petrological context (i.e. the presence of multiple and varied pseudomorphs and coronas), the early monazite retains its primary chemical and isotope characteristics. It only partially recrystallizes via in situ dissolution/reprecipitation during HP metamorphic (possibly dehydration) reactions. In neighbouring samples following the same petrological evolution, when monazite coronas are absent, the HP Variscan event is not 
recorded by the monazite. This demonstrates that petrological processes governed the closure of isotopic systems in monazite and ages obtained in monazite date its own crystallization.

For this reason, monazite is a very good tracer of the petrological processes, unlike zircon, which cannot easily be used as a petrochronometer. As it is usually associated with allanite, apatite or xenotime, with which it shares its constituent elements, monazite exhibits textures that directly reflect the metamorphic reactions. Thus dating successive metamorphic stages following the prograde or retrograde sequence of rare earth minerals along a single polymetamorphic orogenic cycle is quite easy, providing in situ ages in microstructural context. Some nice examples exist in the literature (Janots et al. 2008; Janots et al. 2009; Regis et al. 2014). Skrzypek et al. (2016) provide textural and geochronological arguments to constrain monazite petrogenesis and the age of metamorphic events in medium-grade metasedimentary rocks from the Orlica-Śnieżnik Dome (Czech Republic/Poland). A first monazite generation formed via allanite breakdown during garnet growth at prograde to peak P-T conditions $\left(5-7 \mathrm{kbar}, 575-640{ }^{\circ} \mathrm{C}\right)$ at around $360-340 \mathrm{Ma}$. Retrograde processes are responsible for the dominant monazite age population of 330-310 Ma ascribed to a combination of (1) transient monazite growth after allanite and controlled by P availability, (2) variable recrystallization/ replacement of older monazite grains, and (3) minor monazite neoformation due to the resorption of garnet or apatite. These successive episodes of monazite growth evidence the metamorphic reactions involving major and trace minerals during one single orogenic cycle.

If the reactions involving hygrochronometers and major phases are well identified and calibrated in terms of $P-T-A-X$ conditions, and only in this case, they can be used to calculate duration or exhumation rates. As a recent example, Manzotti et al. (2018) propose to evaluate the exhumation rate of the Gran Paradiso and Money Units (Western Alps) by studying the relative timing of the growth and dissolution of the accessory phases. Combining thermodynamic modelling with HP inclusion, textural and chemical data from both major and accessory phases, these authors were able to date the metamorphic peak and retrograde evolution by fixing $P-T$ conditions of the crystallization episodes of allanite, monazite and xenotime (Fig. 11). The whole set of petrochronological data allow to constrain an exhumation rate of the order of $2.2-5 \mathrm{~mm} / \mathrm{a}$ for these HP units. This type of approach gives results that substantially differ from calculations only based on closure temperature estimations. As the $P-T$ signature and chronometry are simultaneously constrained, the results allow much more accurate geodynamic models.

\section{Concluding remarks}

1. Tectonic models are only as good as the weakest link in the quantification of a $P-T-A-X-D-t$ path.

2. Texture-oriented, high-resolution petrography discriminates equilibrium parageneses from fluid-infiltrated, retrogressed portions of mineral grains and from relict phases. chronological record are pristine. The examples presented of monazite and mica petrochronometry illustrate 
607 that intra-grain unequilibrated, patchy heterogeneities of chemical and isotopic compositions record 608 discontinuous growth phenomena (see also Zhu and O'Nions 1990). Retrograde reactions require cation 609 transfer in a chemically open system.

610 4. The diffusivity of the ionic species in dry solids is very slow, and usually does not allow chemical reactions 611 to take place in the absence of fluids. The total absence of fluids is a rare phenomenon in terrestrial rocks.

612 Migration and homogenization of chemical species in rocks are many orders of magnitude faster if they are 613 assisted by fluids, enhanced even more if deformation facilitates the movement of this fluid. The presence of 614 fluids as a free phase at the grain boundaries plays a role of catalyst by decreasing the activation energy 615 necessary for the initiation of a reaction and by promoting the dissolution of the reactants, the ion transport in 616 solution and reprecipitation of products. Even in apparently anhydrous environments such as granulite or 617 eclogite facies all solid-solid pseudomorphose reactions between anhydrous minerals necessarily involve an 618 aqueous fluid phase. This makes all petrochronometer minerals discussed here to hygrochronometers.

619 5. The availability of aqueous fluids and the rejuvenation of mineral ages are linked not only for HFSEdominated minerals (most (Th+U)-bearing chronometers) but even more so for LILE-dominated minerals (alkali-bearing minerals such as micas and feldspars). Both kinds of minerals are hygrochronometers, but as their susceptibility to aqueous fluids is different, they record different episodes in the $P-T-A-X-D-t$ path.

6. Segments of a $P-T-A-X-D-t$ path can be recorded by prograde/peak/retrograde phases if diffusive reequilibration was slower than fluid-assisted, coupled dissolution-reprecipitation. This requirement is met by diamond, zircon, monazite, allanite, rutile, micas, and feldspars, all of which should be viewed as bona fide petrochronometers. It is not met by most $(\mathrm{Th}+\mathrm{U})-\mathrm{He}$ mineral geochronometers, which behave as thermochronometers.

\section{References}

Airaghi L., Warren C.J., de Sigoyer J., Lanari P., Magnin V. (2018) Influence of dissolution/reprecipitation reactions on metamorphic greenschist to amphibolite facies mica 40Ar/39Ar ages in the Longmen Shan (eastern Tibet). J. Metamorph. Geol. 36, 933-958

Allaz J., Berger A., Engi M. and Villa I.M. (2011) The effects of retrograde reactions and of diffusion on 39Ar-40Ar ages of micas. Journal of Petrology 52, 691-716

Arnold A. and Jäger E. (1965) Rb-Sr Altersbestimmungen an Glimmern im Grenzbereich zwischen voralpinen Alterswerten und alpiner Verjüngung der Biotite. Eclogae Geologicae Helvetiae, 58, 369-390.

Aumar C. (2018) Cinématique, métamorphisme et marqueurs géochronologiques de l'extension crétacée du massif hercynien de l'Agly (Pyrénées orientales). Master Research, Clermont Auvergne University, France.

Bea F. (1996) Residence of REE, Y, Th and U in granites and crustal protoliths ; implications for the chemistry of crustal melts. J. of Petrol. 37, 521-552.

Bosse V., Boulvais P., Gautier P., Tiepolo M., Ruffet G., Devidal J.L., Cherneva Z., Gerdjikov I. and Paquette J.L. (2009). Fluid-induced disturbance of the monazite $\mathrm{Th}-\mathrm{Pb}$ chronometer: in situ dating and element mapping in pegmatites from the Rhodope (Greece, Bulgaria). Chemical Geology, 261, 286-302

Bosse V., Godard G. and Shea T. (2010) Datations des événements polymétamorphiques : intérêts majeurs de l'analyse in situ par ablation laser dans la monazite (Complexe des Essarts, Vendée) Réunion des sciences de la Terre 2010 (Bordeaux, France)

Budzyn B, Harlov DE, Williams ML, Jercinovic MJ (2011) Experimental determination of stability relations between monazite, fluorapatite, allanite, and REE-epidote as a function of pressure, temperature, and fluid composition. Am Mineral 96:1547-1567

Burgess R., Layzelle E., Turner G. and Harris J.W. (2002) Constraints on the age and halogen composition of mantle fluids in Siberian coated diamonds. Earth and Planetary Science Letters 197, 193-203 
Centrella S., Austrheim H., Putnis A. (2016) Mass transfer and trace element redistribution during hydration of granulites in the Bergen Arcs, Norway. Lithos, 262, 1-10

Chafe A.N., Villa I.M., Hanchar J.M. and Wirth R. (2014) A re-examination of petrogenesis and ${ }^{40} \mathrm{Ar} /{ }^{39} \mathrm{Ar}$ systematics in the the Chain of Ponds K-feldspar: "diffusion domain" archetype versus polyphase hygrochronology. Contributions to Mineralogy and Petrology 167(5), paper 1010, 1-17, doi: 10.1007/s00410-014-1010-x

Chakraborty S. and Ganguly J. (1992) Cation diffusion in aluminosilicate garnets: experimental determination in spessartine-almandine diffusion couples, evaluation of effective binary diffusion coefficients, and applications. Contributions to Mineralogy and Petrology, 111, 74-86

Chelalou R., Nalpas T., Bousquet R., Prevost M., Lahfid A., Poujol M., Ringenbach J.-C. and Ballard J.-F. (2016) New Sedimentological, Structural and Paleo-Thermicity Data in the Boucheville Basin (eastern North Pyrenean Zone, France). Comptes Rendus Géoscience 348, 312-321.

Cherniak, D.J., (2006) $\mathrm{Pb}$ and rare earth element diffusion in xenotime. Lithos 88, 1-14.

Cherniak D.J. (2010) Diffusion in accessory minerals: zircon, titanite, apatite, monazite and xenotime. Rev Mineral Geochem 72:827-869

Cherniak D.J., Watson B.E., Grove M. and Harrison T.M. (2004) Pb diffusion in monazite: a combined RBS/SIMS study. Geochimica et Cosmochimica Acta 68, 829-840.

Cocherie, A., Legendre, O., Peucat, J.-J., Kouamelan, A.N., 1998. Geochronology of polygenetic monazites constrained by in situ electron microprobe Th-U-total lead determination: implications for lead behavior in monazite. Geochim. Cosmochim.Acta 62, 2475-2497.

Didier A., Bosse V., Boulvais P., Bouloton J., Paquette J.L., Montel J.M. and Devidal J.L. (2013) Disturbance versus preservation of $\mathrm{U}-\mathrm{Th}-\mathrm{Pb}$ ages in monazite during fluid-rock interaction: textural, chemical and isotopic in situ study in microgranites (Velay Dome, France). Contrib. Mineral. Petrol. 165, 1051-1072

Didier A., Bosse V., Cherneva Z., Gautier P., Georgieva M., Paquette J.L. and Gerdjikov I. (2014). Syn-deformation fluid-assisted growth of monazite during renewed high-grade metamorphism in metapelites of the Central Rhodope (Bulgaria, Greece) Chemical Geology 381, 206-222

Didier A., Bosse V., Bouloton J., Mostefaoui S., Viala M., Paquette J.L., Devidal J.L., Duhamel R. (2015). NanoSIMS mapping and LA-ICP-MS chemical and U-Th-Pb data in monazite from a xenolith enclosed in ndesite (Central Slovakia Volcanic Field). Contribution to Mineralogy \& Petrology vol.170, p.45, doi:10.1007/s00410-015-1200-1.

Dodson, M. H., 1973. Closure temperature in cooling geochronological and petrological systems. Contr. Miner. Petrol., 40, 259-274.

Dumond G, McLean N, Williams M, Jercinovic M, Bowring S (2008) High-resolution dating of granite petrogenesis and deformation in a lower crustal shear zone: Athabasca granulite terrane, western Canadian Shield. Chemical Geology, 254:175-196.

Erickson T.M., Pearce M.A., Taylor R.J.M., Timms N.E., Clark C., Reddy S.M. and Buick I.S. (2015) Deformed monazite yields high-temperature tectonic ages. Geology, 44, 635-638

Ewing T.A., Beltrando M., Müntener O. (2017) U-Pb thermochronology of rutile to constrain the exhumation history of the lower crust: an example from Alpine Corsica. Abstracts, Congresso Società Geologica Italiana, p. 377. doi: 10.3301/ABSGI/2017.01

Fougerouse D., Reddy S.M., Saxey D.W., Erickson T.M., Kirkland C.L., Rickard W.D.A, Seydoux-Guillaume A.M., Clark C. and Buick I.S. (2018) Nanoscale distribution of $\mathrm{Pb}$ in monazite revealed by atom probe microscopy. Chemical Geology 479, 251-268. https://doi.org/10.1016/j.chemgeo.2018.01.020

Gardés E, Jaoul O, Montel JM, Seydoux-Guillaume AM, Wirth R (2006) Pb diffusion in monazite: an experimental study of $\mathrm{Pb}^{2+}+\mathrm{Th}^{4+} \leftrightarrow 2 \mathrm{Nd}^{3+}$ interdiffusion. Geochim. Cosmochim. Acta 70, 2325-2336.

Gautier P. Bosse V. , Cherneva Z., Didier A., Gerdjikov I. And Tiepolo M. (2017). Polycyclic alpine orogeny in the Rhodope Metamorphic Complex: the record in migmatites from the Nestos Shear Zones (N. Greece). Bull. Soc. Géol. France - Earth Sciences Bulletin 188, 2017, 36 DOI: 10.1051/bsgf/2017195

Glodny J., Kühn A., Austrheim H. (2008) Geochronology of fluid-induced eclogite and amphibolite facies metamorphic reactions in a subduction-collision system, Bergen Arcs, Norway. Contr. Miner. Petrol., 156, 27-48

Godard G. (2001): The Les Essarts eclogite-bearing metamorphic complex (Vendee, southern Armorican Massif, France): pre-Variscan terrains in the Hercynian belt? Géol. France, 2001(1-2), 19-51

Godard G. (2009) Two orogenic cycles recorded in eclogite-facies gneiss from the southern Armorican Massif (France) Eur. J. Mineral., 21, 1173-1190

Grand'Homme A., Janots E., Seydoux-Guillaume A.M., Guillaume D., Bosse V. and Magnin V. (2016) Partial resetting of the U-Th-Pb systems in experimentally altered monazite: Nanoscale evidence of incomplete replacement.Geology, v. 44, p. 431-434

Grand'Homme A., Janots E., Seydoux-Guillaume A.M., Guillaume D., Magnin V., Hövelmann J., Höschen C. and Boiron M.C. (2018) Mass transport and fractionation during monazite alteration by anisotropic replacement. Chem. Geol. 484, 51-68

Harlov D. E. and Hetherington C. J. (2010) Partial high-grade alteration of monazite using alkali-bearing fluids: Experiment and nature. Am. Mineral. 95:1105-1108.

Harlov D. E. and Hetherington C. J. (2011) Fluid-mediated partial alteration in monazite: the role of coupled dissolution-reprecipitation in element redistribution and mass transfer. Contrib Mineral Petrol 162:329-348 
Hetherington C.J., Villa I.M., 2007. Barium silicates of the Berisal Complex, Switzerland: A study in geochronology and rare-gas release systematics. Geochim. Cosmochim. Acta 71, 3336-3347.

Hetherington CJ, Harlov DE, Budzyn B (2010) Experimental metasomatism of monazite and xenotime: mineral stability,REE mobility and fluid composition. Contrib. Mineral. Petrol. 99:165-184.

Jäger, E., 1967. Die Bedeutung der Biotit-Alterswerte. In: Rb-Sr Altersbestimmungen an Glimmern der Zentralalpen (Eds E. Jäger, E. Niggli and E. Wenk) Beitr. Geol. Karte Schweiz, NF, 134, 28-31.

Janots E., Engi M., Berger A., Allaz J., Schwarz J-O. and Spandler C. (2008). Prograde metamorphic sequence of REE minerals in pelitic rocks of the Central Alps: implications for allanite-monazite-xenotime phase relations from 250 to $610^{\circ} \mathrm{C}$. J. Metamorphic Geol., 2008, 26, 509-526.

Janots E, Engi M, Rubatto D, Berger A., Gregory C, Rahn M (2009) Metamorphic rates in collisional orogeny from in situ allanite and monazite dating. Geology 37:11-14.

Janots E, Berger A, Gnos E, Whitehouse M, Lewin E, Pettke T (2012) Constraints on fluid evolution during metamorphism from U-Th-Pb systematics in Alpine hydrothermal monazite. Chem Geol 326-327:61-71

Kirkland C.L., Yakymchuk C. Szilas K., Evans N., Hollis J., McDonald B., Gardiner N.J. (2018) Apatite: a U-Pb thermochronometer or geochronometer? Lithos, 318-319, 143-157

Kohn M.J. (2013). Geochemical zoning in metamorphic minerals. In: Treatise on Geochemistry, v. 3: The Crust (R. Rudnick, ed.). Elsevier, 2nd edition. 249-280.

Kohn M.J. (2016) Metamorphic chronology —a tool for all ages: Past achievements and future prospects. American Mineralogist, Volume 101, pages 25-42, 2016

Kramers J.D., Frei R., Newville M., Kober B., Villa I.M. (2009) On the valency state of radiogenic lead in zircon and its consequences. Chem. Geol., 261, 3-10

Kusiak M.A., Whitehouse M.J., Wilde S.A., Nemchin A.A. and Clark C. (2013) Mobilization of radiogenic Pb in zircon revealed by ion imaging: Implications for early Earth geochronology. geology v. 41; no. 3; p. 291-294

Kylander-Clark A.R.C., Hacker B.R. and Cottle J.M. (2013) Laser-ablation split-stream ICP petrochronology, Chemical Geology 345, 99-112

Labotka T.C., Cole D.R., Fayek M., Riciputi L.R. and Stadermann F.J. (2004) Coupled cation and oxygen-isotope exchange between alkali feldspar and aqueous chloride solution. American Mineralogist, 89, 1822-1825

Maineri C., Benvenuti M., Costagliola P., Dini A., Lattanzi P.F., Ruggieri G., Villa I.M. (2003) Alkali-metasomatic processes at La Crocetta raw ceramic material mine (Elba Island, Italy): interplay between magmatism, tectonics and mineralization. Mineralium Deposita, 38, 67-86

Malusà M.G., Danišík M., Kuhlemann J. (2016) Tracking the Adriatic-slab travel beneath the Tethyan margin of Corsica-Sardinia by low-temperature thermochronometry. Gondwana Res. 31, 135-149

Manzotti P., Bosse V., Pitra P., Robyr M., Schiavi F. and Ballevre M. (2018) Exhumation rates in the Gran Paradiso Massif (Western Alps) constrained by in situ U-Th-Pb dating of accessory phases (monazite,allanite and xenotime). Contributions to Mineralogy and Petrology (2018) 173:24 https://doi.org/10.1007/s00410-018-1452-7

Montel, J.-M., Foret, S., Veschambre, M., Nicollet, C., Provost, A., 1996. Electron microprobe dating of monazite. Chem. Geol. 131, 37-53.

Mottram C. M, Warren C.J., Regis D., Roberts N.N.W., Harris N.B.W., Argles T.W. and Parrish R.R. (2014) Developing an inverted Barrovian sequence; insights from monazite petrochronology. Earth Planet. Sci. Lett. 403, 418-431

Mukai H., Austrheim H., Putnis C.V., Putnis A. (2014) Textural Evolution of Plagioclase Feldspar across a Shear Zone: Implications for Deformation Mechanism and Rock Strength J. Petrol. 55, 1457-1477

Naumenko-Dèzes, M.O., Rolland Y., Lanari P., Villa I.M., 2018. Intra-grain chronological and compositional inhomogeneity of magmatic micas. Abstract, AGU Fall Meeting, Washington, December 2018

Nicolas R. "Etude Géochronologique et Pétrostructurale Du Massif de l’Agly,", Master research, Montpellier University, France, 1998.

Poitrasson F, Chenery S, Bland DJ (1996) Contrasted monazite hydrothermal alteration mechanisms and their geochemical implications. Earth Planet. Sci. Lett. 145:79-96.

Putnis A (2002) Mineralogical replacement reactions: from macroscopic observations to microscopic mechanisms. Mineral.Mag. 66:689-708.

Putnis A, (2009) Mineral Replacement Reactions. Rev. Mineral. Geochemistry 70, 87-124.

Putnis A. and Austrheim H. (2013) Mechanisms of metasomatism and metamorphism on the local mineral scale: the role of dissolution-reprecipitation during mineral re-equilibration. In: Harlov D.E., Austrheim H. (eds.),

Metasomatism and the Chemical Transformation of Rock. Springer, Heidelberg, 141-170. ISBN 978-3-642-28393-2.

Putnis A. and John, T. (2010) Replacement Processes in the Earth's Crust. Elements, 6, 159-164

Regis D., Rubatto D., Darling J., Cenki-Tok B., Zukali M. and Engi M. (2014) Multiple Metamorphic Stages within an Eclogite-faciesTerrane (Sesia Zone, Western Alps) Revealed byTh-U-Pb Petrochronology. J. of Petrol. 55, 14291456

Richard A, Montel J-M, Leborgne R, Peiffert C, Cuney M, Cathelineau M (2015) Monazite Alteration in $\mathrm{H} 2 \mathrm{O} \pm \mathrm{HCl} \pm$ $\mathrm{NaCl} \pm \mathrm{CaCl} 2$ Fluids at $150^{\circ} \mathrm{C}$ and $\mathrm{p}_{\text {sat }}$ : Implications for Uranium Deposits. Minerals 5:693-706

Schärer, U., Hamet, J., Allègre, C.J., 1984. The Transhimalaya (Gangdese) plutonism in the Ladakh region: a U-Pb and Rb-Sr study. Earth and Planetary Science Letters 67, 327-339. 
Seydoux-Guillaume, A.M., Wirth, R., Nasdala, L.,Gottschalk, M., Montel, J.M., and Heinrich, W., (2002a), An XRD, TEM and Raman study of experimentally annealed natural monazite: Physics and Chemistry of Minerals, v. 29, p. 240-253.

Seydoux-Guillaume, A.M., Paquette, J.L., Wiedenbeck, M., Montel, J.M., and Heinrich, W., (2002b), Experimental resetting of the U-Th-Pb system in monazite: Chemical Geology, v. 191, p. 165-181.

Seydoux-Guillaume A.M., Goncalves P., R. Wirth, A. Deutsch (2003) Transmission electron microscope study of polyphase and discordant monazites: Site-specific specimen preparation using the focused ion beam technique Geology; v. 31; no. 11; p. 973-976

Seydoux-Guillaume A.M., Wirth R., Deutsch A. and Schärer U. (2004) Microstructure of 24-1928 Ma concordant monazites; implications for geochronology and nuclear waste deposits. Geochimica et Cosmochimica Acta, Vol. 68, No. 11, pp. 2517-2527

Skrzypek E., Bosse V., Kawakami T., Martelat J.E. and Štípská P. (2016) Transient allanite replacement and prograde to retrograde monazite (re)crystallization in medium-grade metasedimentary rocks from the Orlica-Śnieżnik Dome (Czech Republic/Poland): Textural and geochronological arguments. Chemical Geology, http://dx.doi.org/10.1016/j.chemgeo.2016.11.033

Steck A. and Hunziker J. (1994) - The tertiary structural and thermal evolution of the Central Alps - compressional and extensional structures in an orogenic belt. Tectonophysics, 238, 229-254.

Tartèse R., Ruffet G., Poujol M., Boulvais P., Ireland T.R. (2011) - Simultaneous resetting of the muscovite K-Ar and monazite U-Pb geochronometers: a story of fluids. Terra Nova, 23, 390-398.

Teufel S, Heinrich W (1997) Partial resetting of the U-Pb isotope system in monazite through hydrothermal experiments: an SEM and U-Pb isotope study. Chemical Geology 137:273-281.

Townsend KJ, Miller CF, D'Andrea JL, Ayers JC, Harrison TM and Coath CD (2001) Low temperature replacement of monazite in the Ireteba granite, Southern Nevada: geochronological implications. Chem Geol 172:95-112.

Valley, J.W., Cavosie, A.J., Ushikubo, T., Reinhard, D.A., Lawrence, D.F., Larson, D.J., Clifton, P.H., Kelly, T.F., Wilde, S.A., Moser, D.E., Spicuzza, M.J., 2014. Hadean age for a postmagma- ocean zircon confirmed by atomprobe tomography. Nat. Geosci. 7, 219-223.

Vance D., Müller W., Villa I.M., 2003. Geochronology: linking the isotopic record with petrology and textures - an introduction. In: Vance D., Müller W., Villa I.M. (eds) Geochronology: linking the isotopic record with petrology and textures. Geological Society London Special Publications, 220, 1-24.

Villa I.M. (1998) Isotopic closure. Terra Nova, 10,42-47

Villa I.M. (2010) - Disequilibrium Textures vs Equilibrium Modelling: Geochronology at the Crossroads. In: Spalla M.I., Marotta A.M., Gosso G. (eds) Advances in interpretation of geological processes. Geological Society London Special Publications, 332, 1-15.

Villa I.M. (2016) Diffusion in mineral geochronometers: Present and absent. Chemical Geology, 420, 1-10

Villa I.M. and Williams M.L. (2013) - Geochronology of metasomatic events. In: Harlov D.E., Austrheim H. (eds.), Metasomatism and the Chemical Transformation of Rock. Springer, Heidelberg, 171-202. ISBN 978-3-642-28393-2.

Villa I.M., Bucher S., Bousquet R., Kleinhanns I.C. and Schmid S.M. (2014) Dating polygenetic metamorphic assemblages along a transect through the Western Alps. Journal of Petrology, 55, 803-830

Villa I.M. and Hanchar J.M. (2017). Age discordance and mineralogy. American Mineralogist, 102, 2422-2439.

Wartho J.A., Kelley S.P., Brooker R.A., Carroll M.R., Villa I.M. and Lee M.R. (1999) Direct Ar diffusion measurements in a gem-quality Madagascar K-feldspar using the Ultra-Violet Laser Ablation Microprobe (UVLAMP). Earth and Planeary Science Letters, 170, 141-153

Wawrzenitz, N., Krohe, A., Rhede, D., Romer, R.L., (2012). Dating rock deformation with monazite: the impact of dissolution precipitation creep. Lithos 132-135, 52-74.

Whitehouse M.J., Kusiak M.A., Wirth R. and Ravindra Kumar, G.R. (2017) Metallic Pb nanospheres in ultra-high temperature metamorphosed zircon from southern India. Mineralogy and Petrology 111, 467-474

Williams, M.L., Jercinovic, M.J. (2002). Microprobe monazite geochronology: putting absolute time into microstructural analysis. J. Struct. Geol. 24, 1013-1028.

Williams ML, Jercinovic MJ, Terry M (1999) High resolution « age » mapping, chemical analysis, and chemical dating of monazite using the electron microprobe : a new tool for tectonic analysis. Geology 27: 1023-26

Williams ML, Jercinovic MJ, Hetherington CJ (2007) Microprobe monazite geochronology: understanding geologic processes by integrating composition and chronology. Annual Review of Earth Planet Sci Leters 35:137-175.

Williams ML, Jercinovic MJ, Harlov DE, Budzyń B, Hetherington CJ (2011) Resetting monazite ages during fluidrelated alteration. Chem Geol 283:218-225

Williams M.L., Jercinovic M.J., Mahan K.H. and Dumond G. (2017) Electron Microprobe Petrochronology. Reviews in Mineralogy and Geochemistry 83, 153-182

Zhu XK, O'Nions RK (1999) Zonation of monazite in metamorphic rocks and its imlications for high temperature thermochronology: a case study from the Lewisian terrain. Earth Planet. Sci. Lett. 171:209-220. 
1. Arrhenius diagram showing diffusion coefficients for garnet (Chakraborty and Ganguly, 1992) and monazite (Cherniak et al. 2004).

2. Different types of monazite zonations (EPMA X ray maps). (Didier et al. 2014; Didier et al. 2015; Bosse et al. 2009). (b) NanoSIMS distribution maps $\left({ }^{89} \mathrm{Y},{ }^{139 \mathrm{La}},{ }^{238} \mathrm{U},{ }^{208} \mathrm{~Pb},{ }^{232} \mathrm{Th}\right.$ and $\left.{ }^{208} \mathrm{~Pb} /{ }^{232} \mathrm{Th}\right)$, RGB maps ( $\mathrm{Y}$ in red, Th in green and $\mathrm{U}$ in blue) and interpretive sketches of selected portions of Monazite. The sketches distinguish between the M1 (red), M2 (green) and M3 (orange) domains corresponding to successive monazite growth stages. Didier et al. (2015)

3. Inverse relation between assumed "closure temperature" and age of peak metamorphism in a traverse across the Central Alps. The $\mathrm{x}$ axis is eastings, for convenience indicated as peak metamorphic temperature. (a) By assuming an excessively low retentivity of ${ }^{87} \mathrm{Sr}^{*}$ in muscovite (dashed), monazite (solid line) is inferred to record cooling below ca. $450{ }^{\circ} \mathrm{C}$ (redrawn after Steck and Hunziker 1994). (b) By assuming that monazite always dates its own crystallization, and thus the metamorphic peak, most muscovite samples record isotopic inheritance of ${ }^{87} \mathrm{Sr}^{*}$ even at $650{ }^{\circ} \mathrm{C}$. The tectonic implications are far-reaching: the exhumation rates and differential movements of the tectonic units in (b) is radically different from the incorrect ones in (a), which means that the starting assumption was incorrect.

4. Mineral ages in monometamorphic sediments in the Central Alps (data from Allaz et al. 2011). Peak metamorphism for rock AMo0410 is followed by paragonite destabilization, consumption of the first paragonite generation (Prg-1), and then growth of a Prg-2 after the rock re-entered the paragonite stability field during exhumation. The biotite age lies between the peak age and the age of Prg-2, and corresponds to the sum of chloritization and pure retrogression-free diffusion.

5. Thermochronology vs petrochronology of white mica in a traverse across the Western Alps (data from Villa et al. 2014). (a) Thermochronological prediction: the ages of detrital micas remain high until the "closure temperature" (here shown as $375-400^{\circ} \mathrm{C}$ ) is reached, then decrease continuously as peak temperatures increase. (b) Observation: tha data-points (black circles) demonstrate Ar loss at $\mathrm{T}$ $<300{ }^{\circ} \mathrm{C}$, complete Ar retention at $600{ }^{\circ} \mathrm{C}$, and correlated exchange of Ar and Si at intermediate $\mathrm{T}$. The Ar retention behaves asymptotically, as phengite ages do not become younger as peak temperature increases, but instead remain constant and equal to the Lu-Hf garnet ages. The predictions of thermochronology are all violated, which means that the thermochronologically inferred tectonic history (Cretaceous eclogitization, discrete greenschist event, delayed exhumation) are all incorrect.

Fig. 6 - Alteration experiments on natural monazite crystals under alkali conditions at 400 (A), 500 (B) and 600 (C) ${ }^{\circ} \mathrm{C}$ and $200 \mathrm{MPa}$ (Grand'Homme et al. 2016). A,B, C: Transmission electron microscope images in bright field mode (BF-TEM) from focused ion beam (FIB) foils prepared at the reaction interface of experimental products; D: Energy-dispersive spectroscopy spectrum obtained on primary monazite (Mnz1) and secondary monazite (Mnz2) domains at $500^{\circ} \mathrm{C}$.

Fig. 7 - Tera-Wasserburg diagram of analyses for single grains of altered monazite (filled ellipses), in altered monazite affected by $\mathrm{Pb}$ loss (dashed ellipses), pristine monazite and an inherited monazite (empty ellipses) from the Montasset microgranite. Upper inset: ${ }^{208} \mathrm{~Pb} /{ }^{232} \mathrm{Th}$ age probability histogram for all altered monazite grains; Right inset: X-ray Th element map of a hydrothermal monazite grain (Didier et al. 2013)

Fig. 8 - BSE images of monazite from the Rhodope Grt-Ky metapelites showing evidences of syndeformation fluid-assisted monazite growth (Didier et al. 2014).

Fig. 9 - BSE images and yttrium X-ray maps of matrix monazites in the Rhodope Grt-Ky metapelites (Didier et al. 2014). Circles show the location of the LA-ICPMS pits $(11 \mu \mathrm{m})$ and their corresponding ${ }^{208} \mathrm{~Pb} /{ }^{232} \mathrm{Th}$ ages (green and orange : concordant ages, white : mixing ages; $2 \sigma$ uncertainty).

Fig. 10 - Monazite textures in eclogite-facies gneiss from the Les Essarts HP unit (Southern Armorican Massif, France): Left : apatite, zoisite and monazite (Mnz 2) developed at contacts between primary monazite (Mnz 1) and plagioclase; kaolinite $(\mathrm{Kln})$ probably results from the late alteration of metamict plagioclase. Image obtained from X-ray element maps, after phase classification (Godard, 2009); Right : 
BSE image and corresponding LA-ICPMS 208Pb/232Th ages (spot size $5 \mu \mathrm{m}, 2 \sigma$ uncertainty) (Bosse et

895 al. 2010)

896 Fig. 10 - Summary of the petrochronological results ( $\mathrm{P}-\mathrm{T}$ paths and monazite ${ }^{208} \mathrm{~Pb} /{ }^{232} \mathrm{Th}$ ages). Note the 897 presence of HP inclusions, which confirm the crystallization of the monazite during HP metamorphism 898 conditions. Money Units (a) and Gran Paradiso (b), modified after Manzotti et al. (2018). 


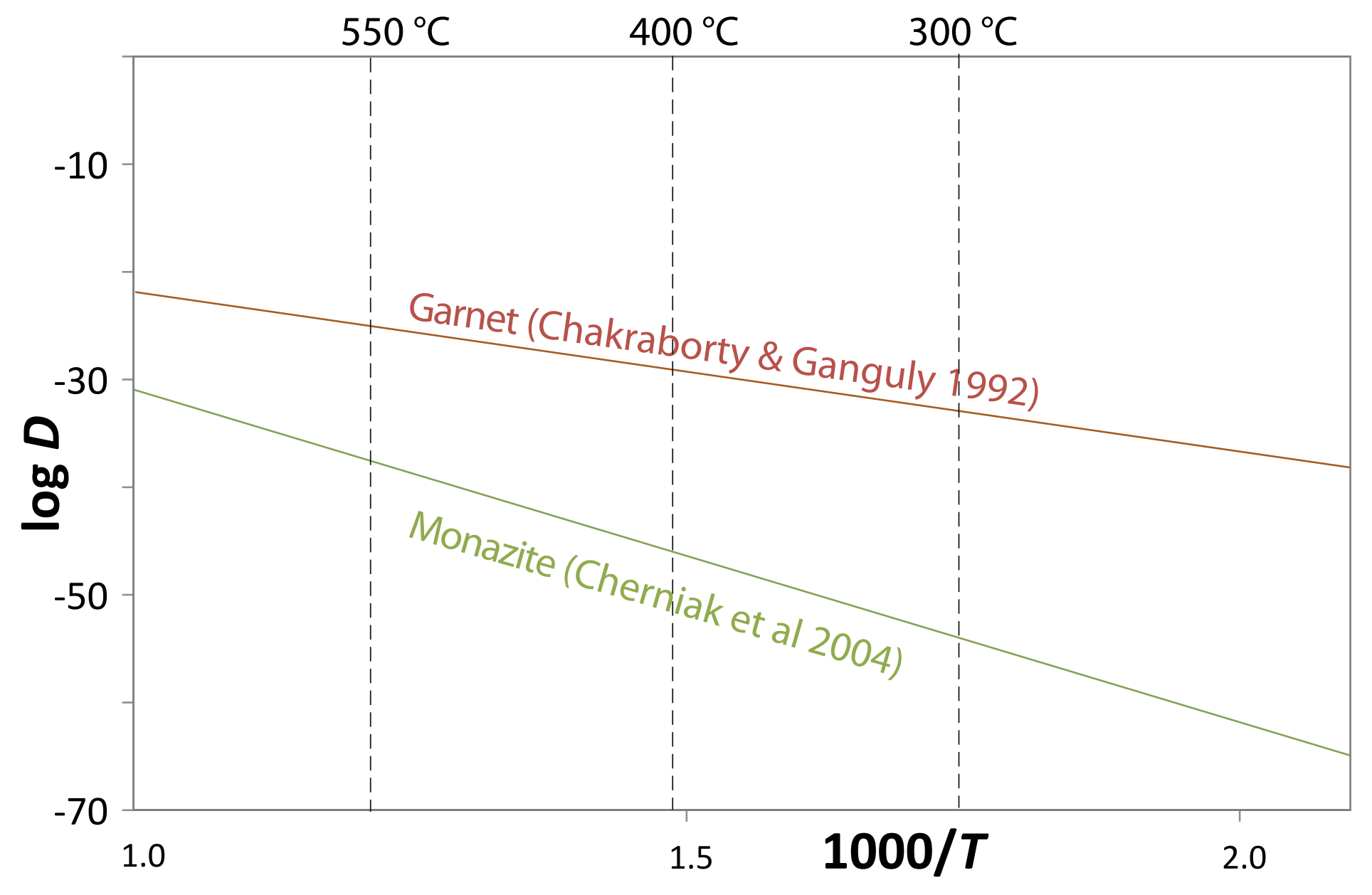




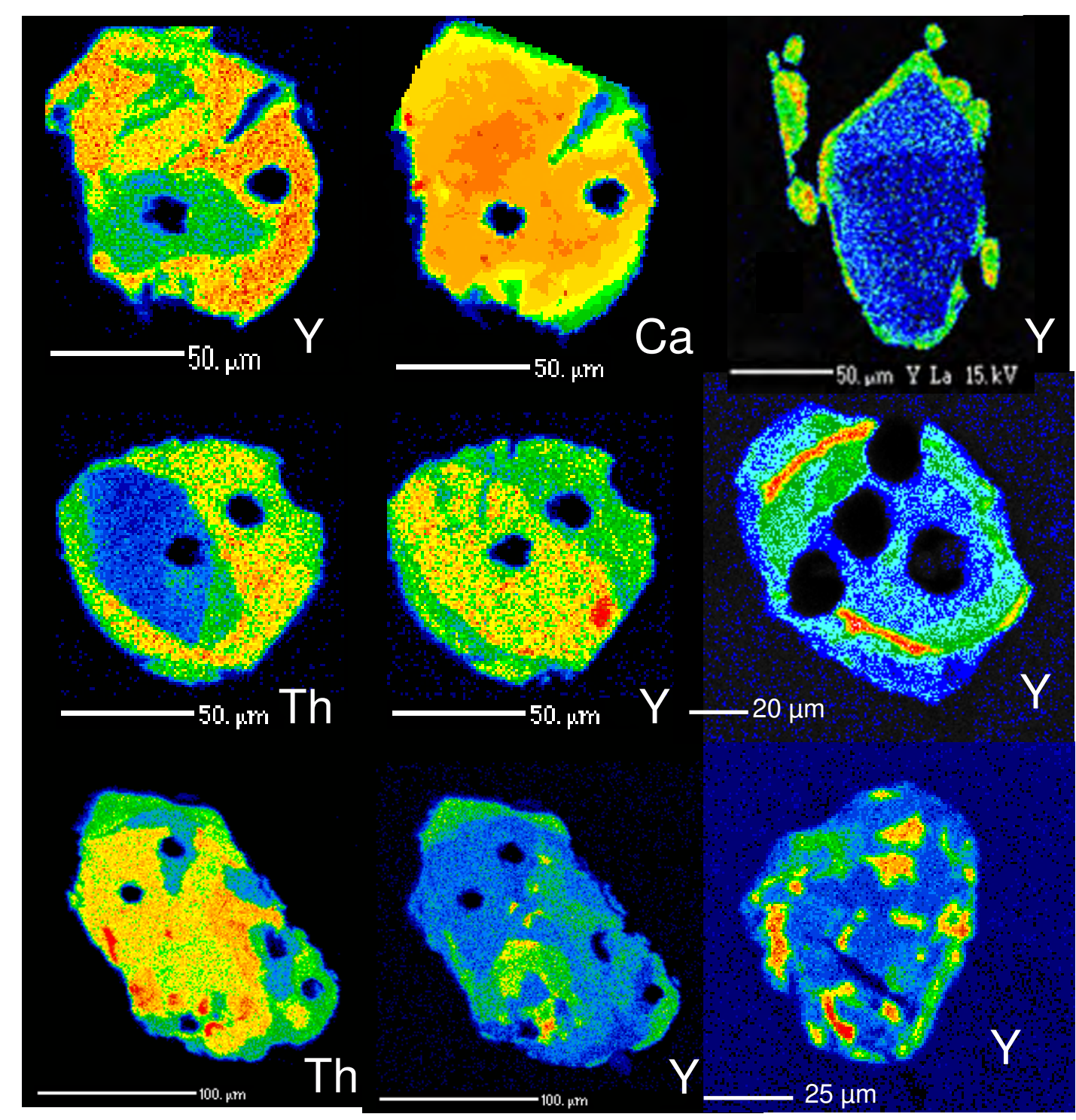

Different types of monazite zonations (EMP $X$ ray maps). (Didier et al. 2014; Didier et al. 2015; Bosse et al. 2009)

Fig. 2a 

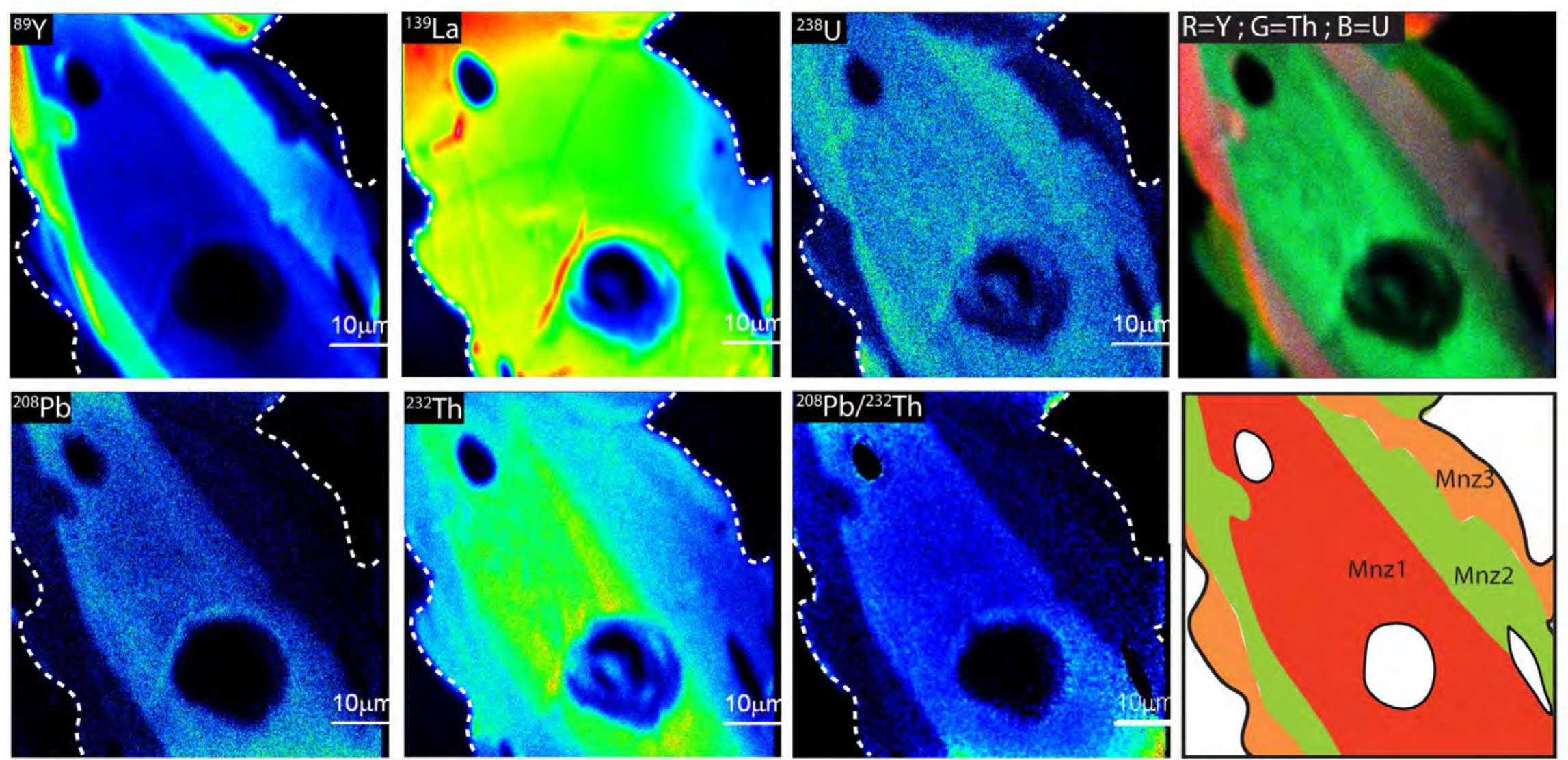

NanoSIMS distribution maps (89Y,139La, 238U, 208Pb, 232Th and 208Pb/232Th), RGB maps ( $\mathrm{Y}$ in red, Th in green and $\mathrm{U}$ in blue) and interpretive sketches of selected portions of Monazite. The sketches distinguish between the M1 (red), M2 (green) and M3 (orange) domains. Didier et al. (2015)

Fig. 2b 

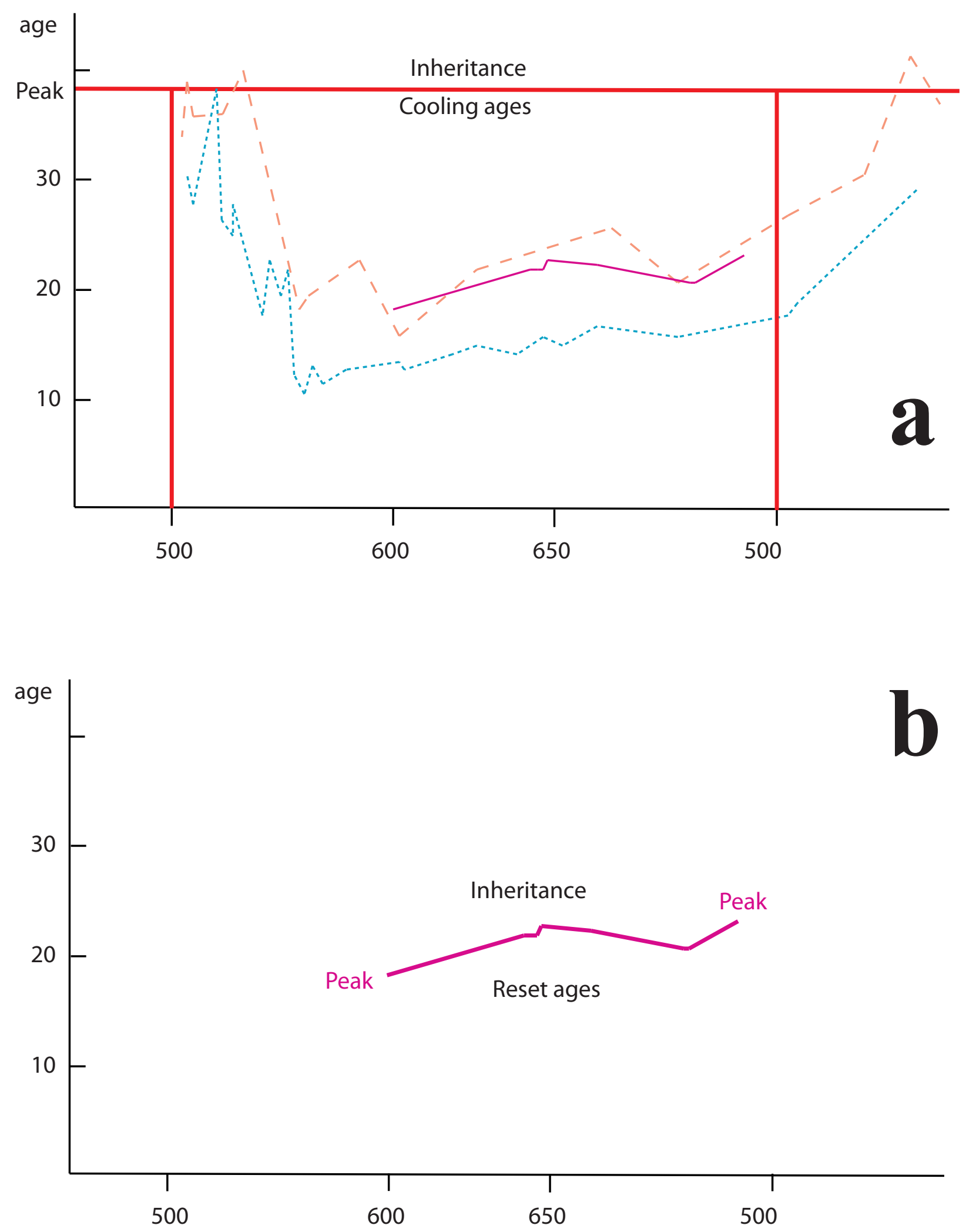


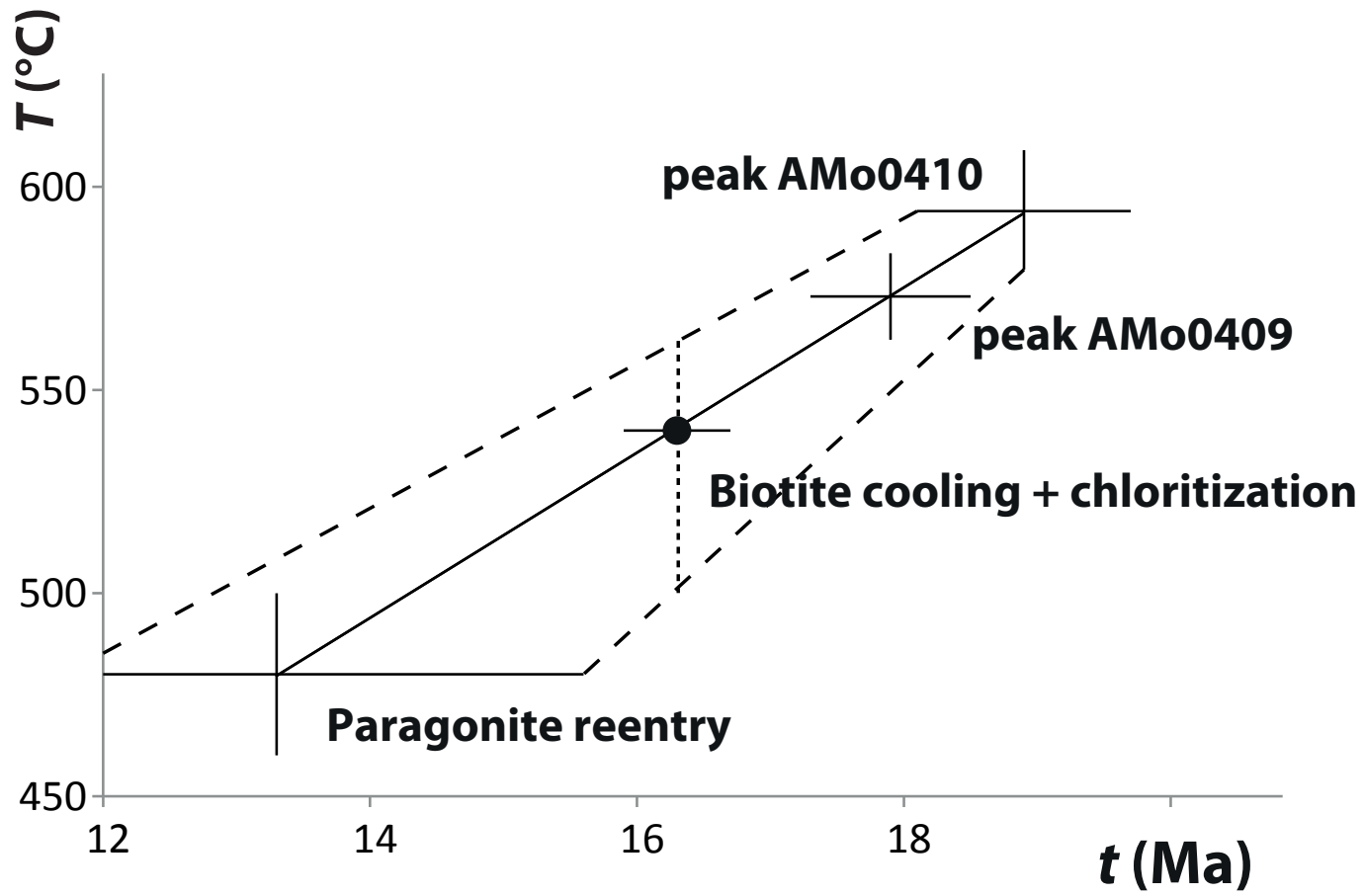

Bosse\&Villa - Fig. 3 

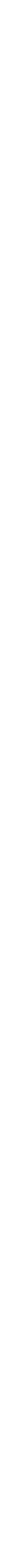

Bosse \& Villa - Fig. 

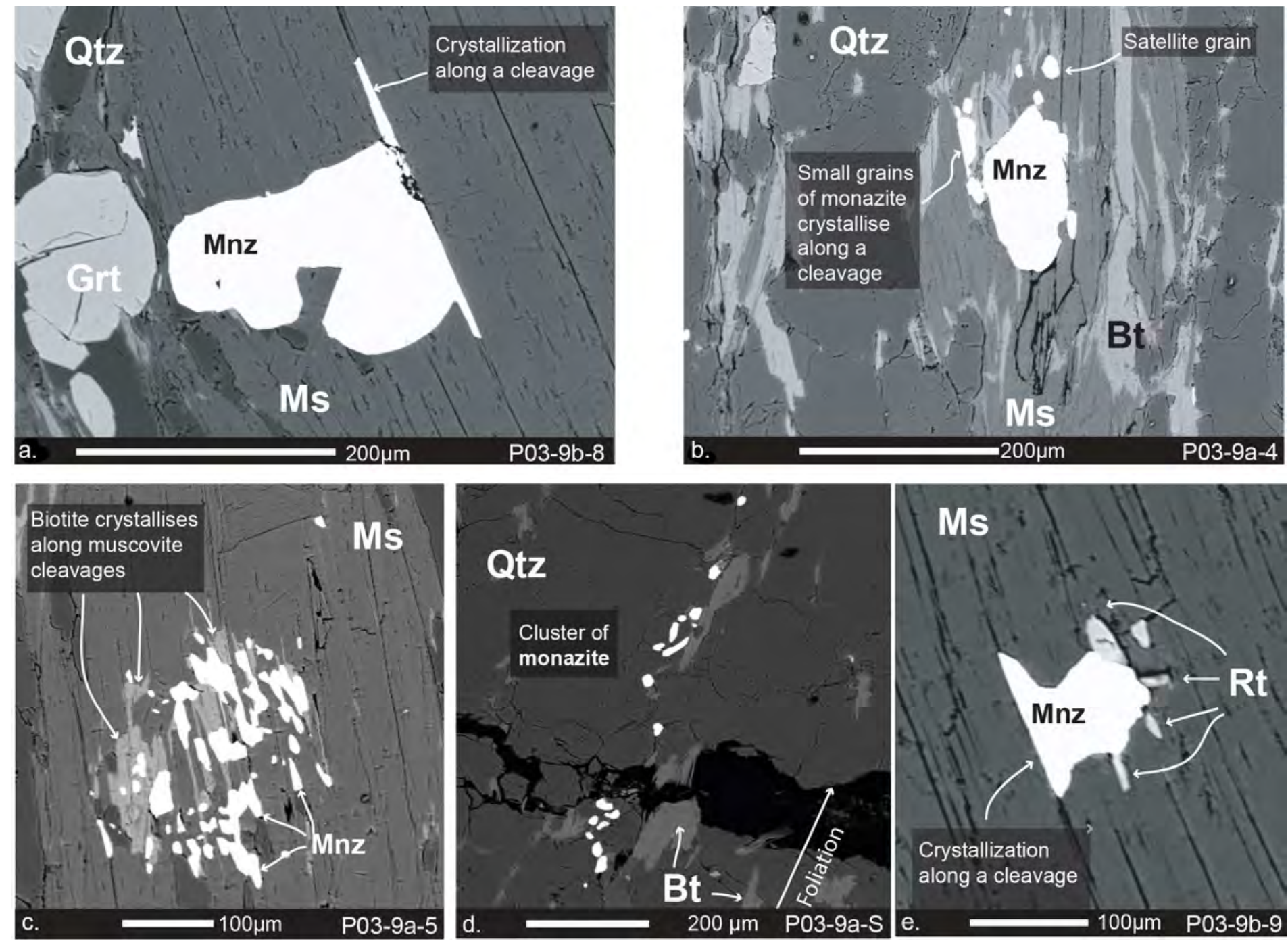

BSE images of monazite from the Rhodope samples (Didier et al. 2014) showing evidences of syn-deformation fluid-assisted monazite growth

Fig. 3 

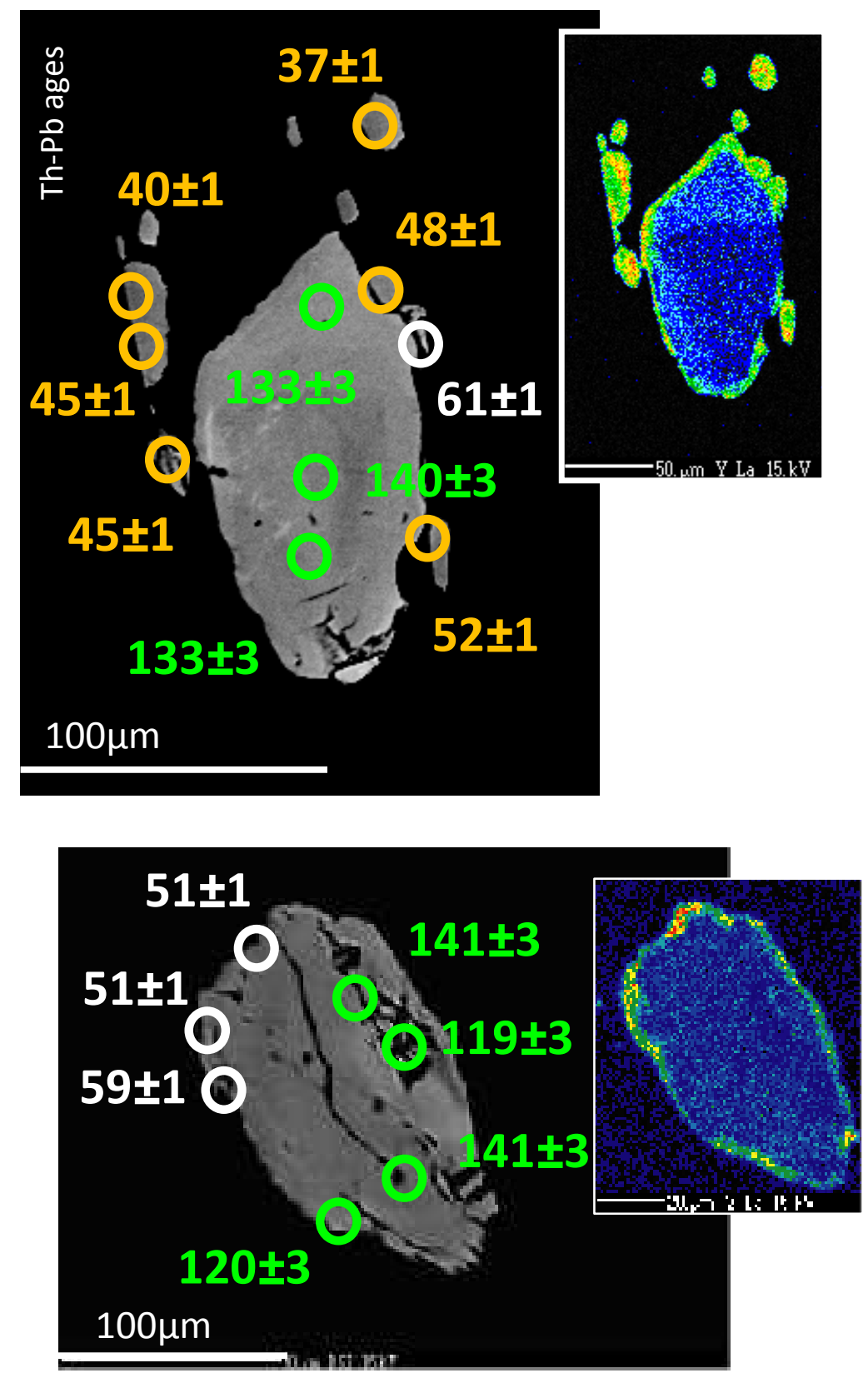

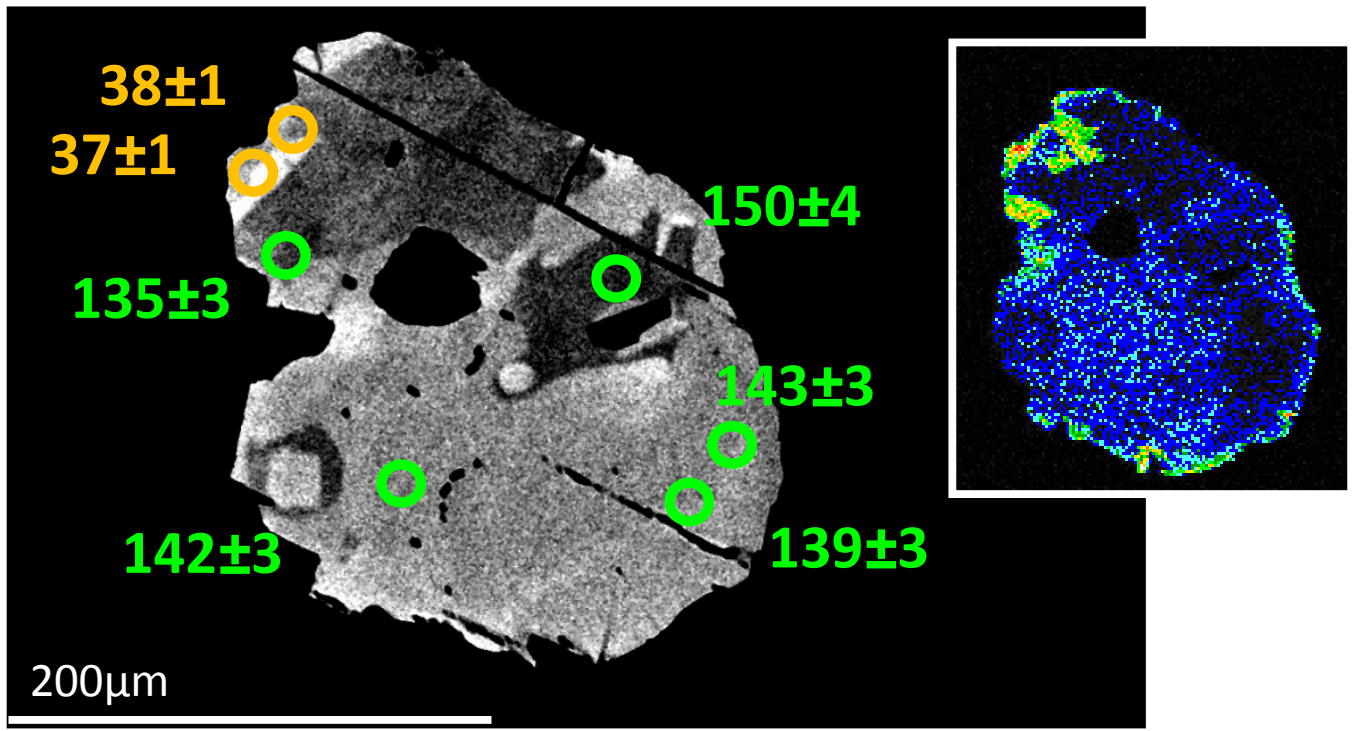

BSE images and $Y X$-ray maps of matrix monazites in the Rhodope samples (Didier et al. 2014) Circles show the location of the LAICPMS pits $(11 \mu \mathrm{m})$ and their corresponding

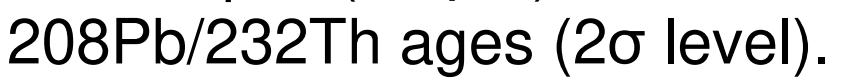

Fig. 4 


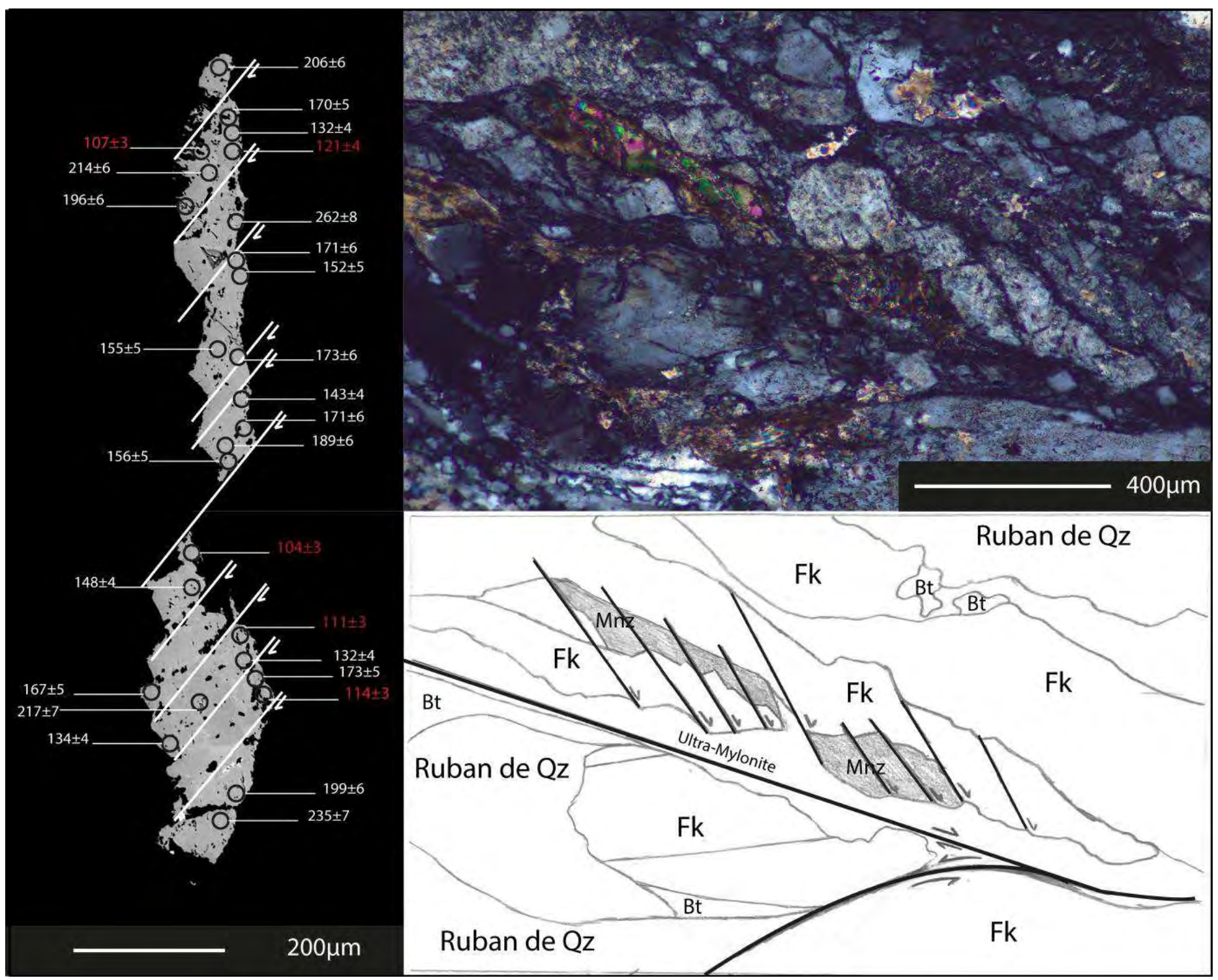

BSE image with 232Th/208Pb ages (spot size 7um). In red, concordant ages and in white mixing (meaningless) ages. Right: Photomicrograph of the monazite texture and sketch showing the deformation.

Fig. 5 


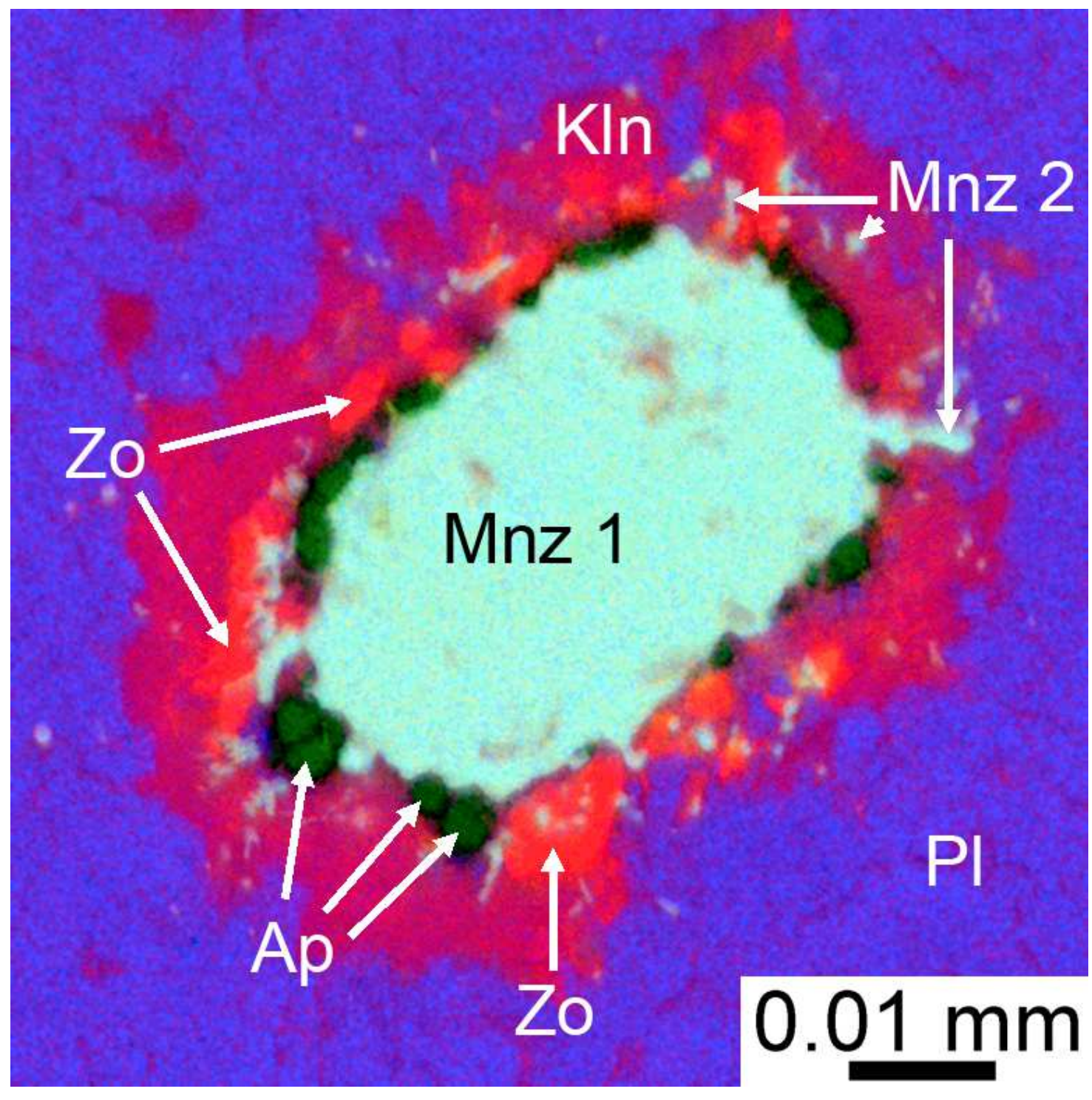

Fig. 6 


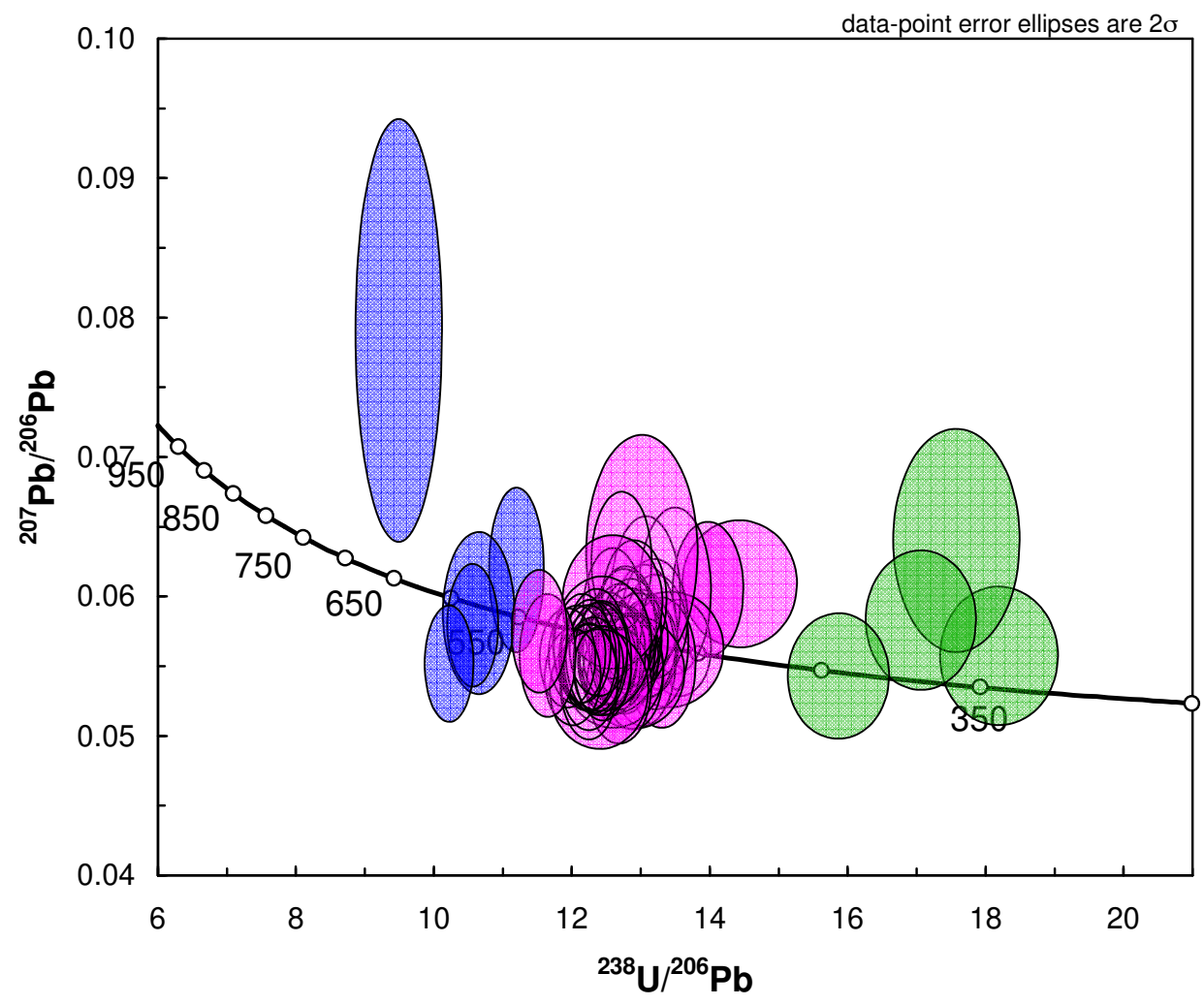

To be improved ...

Tera Wasserburg diagram showing the three monazite generations recorded in the Vendée paragneisses (Bosse et al. 2010)

Fig. 7 


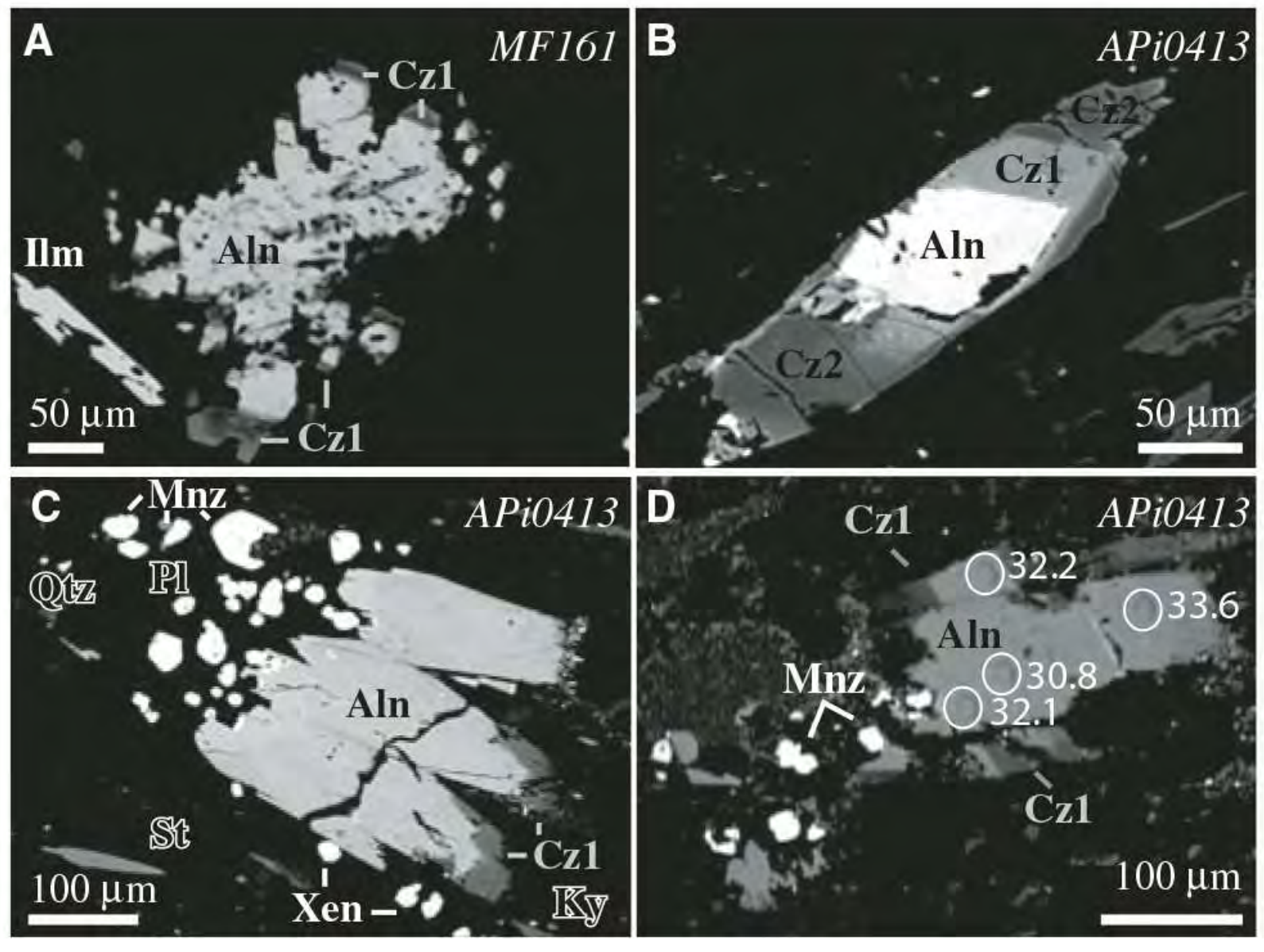

Janots et al. 2009...

Fig. 8 

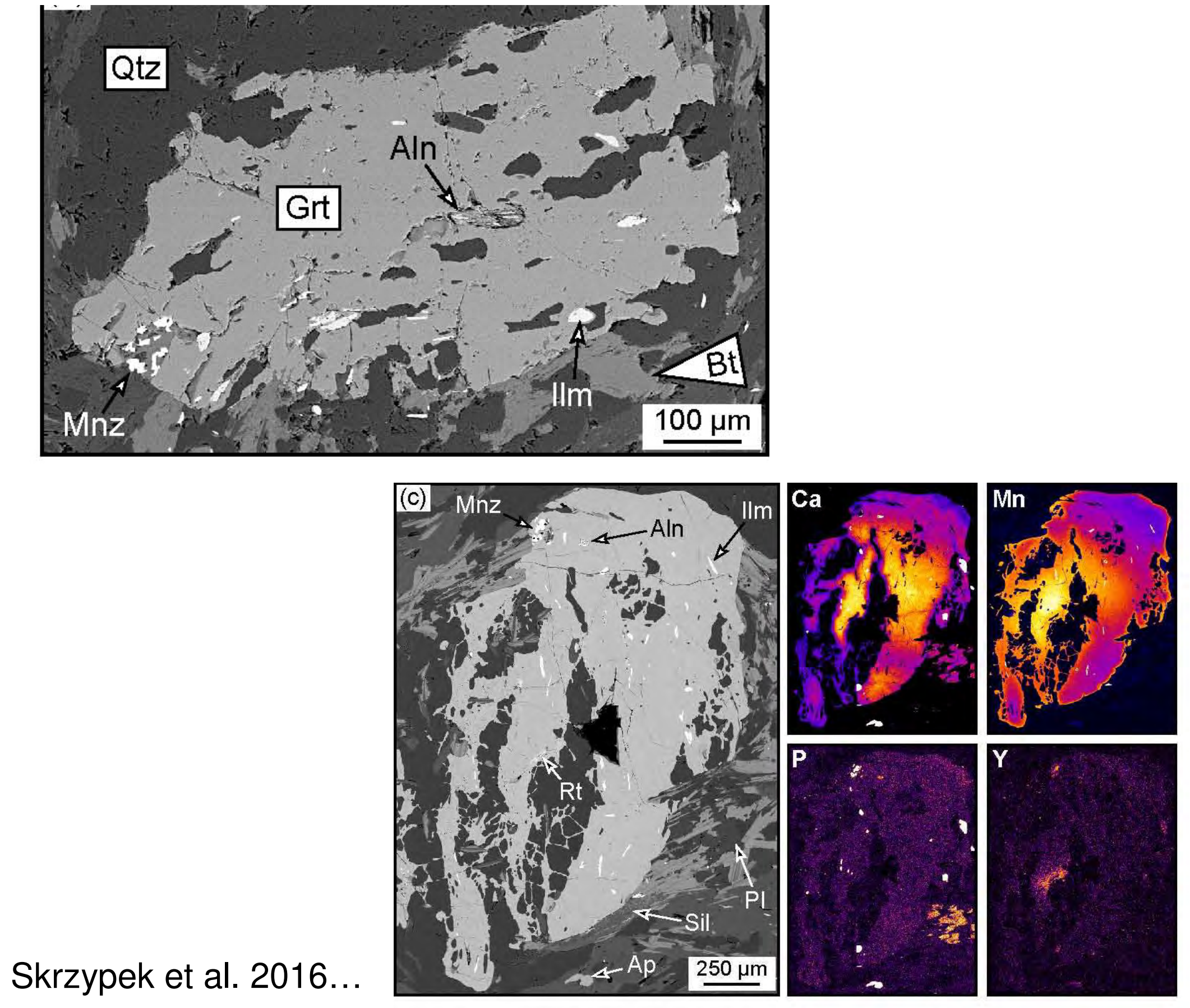

Fig. 9 


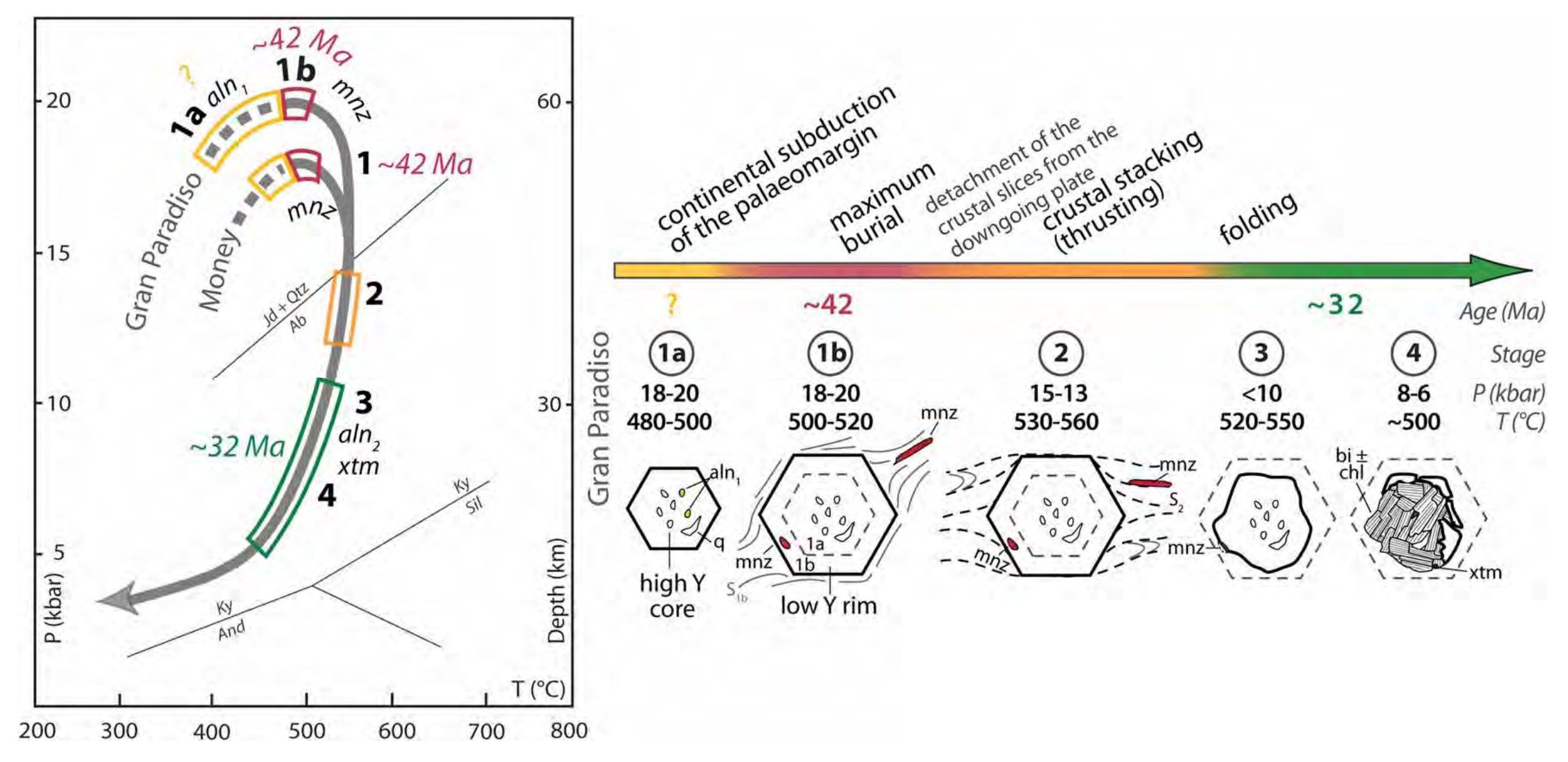

Summary of the petrochronological results ( $P-T$ paths and monazite, allanite and xenotime ages) for the Gran Paradiso and Money Units (Manzotti et al. 2018)

Fig. 10 


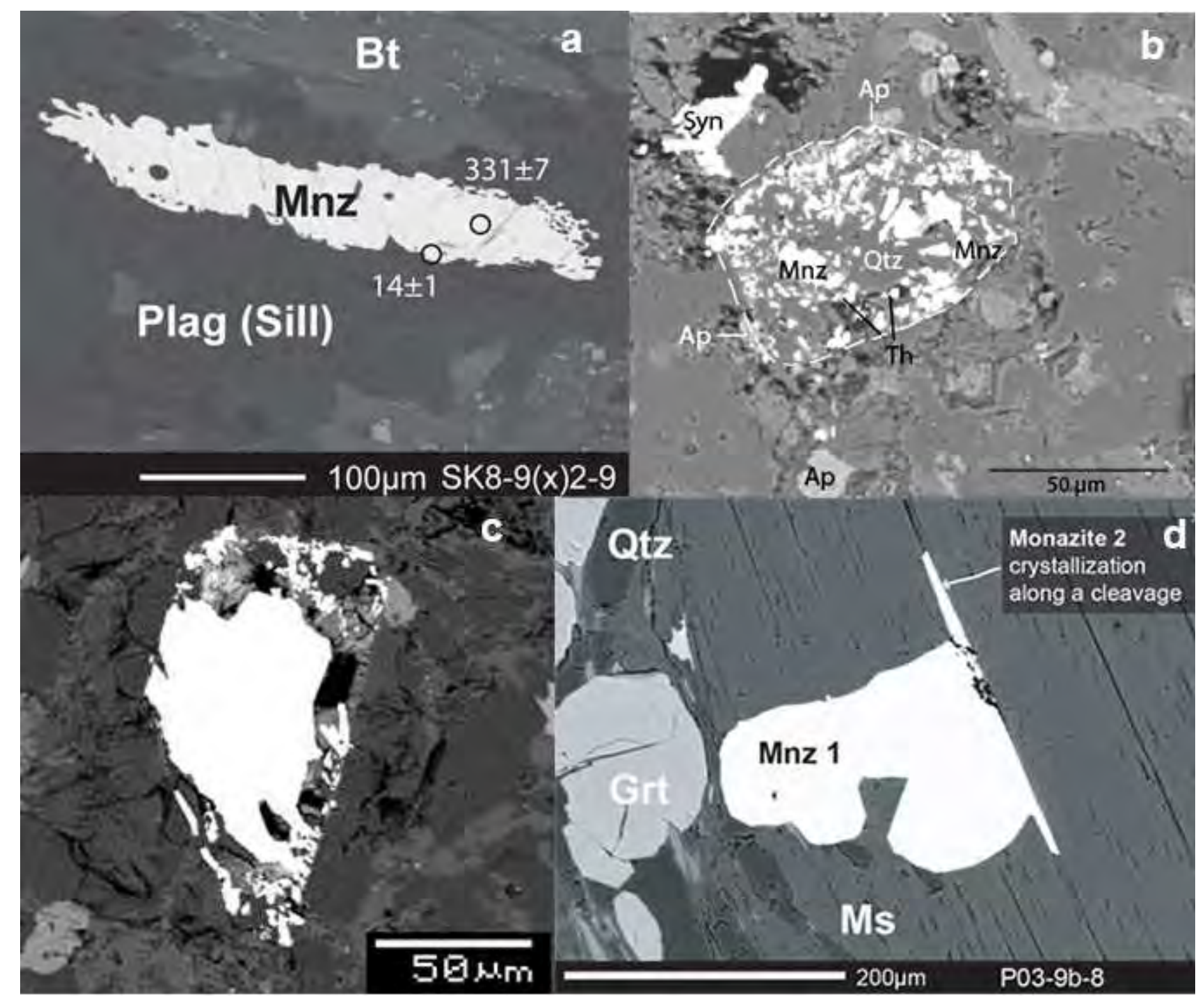

To be modified...

Fig. 11 


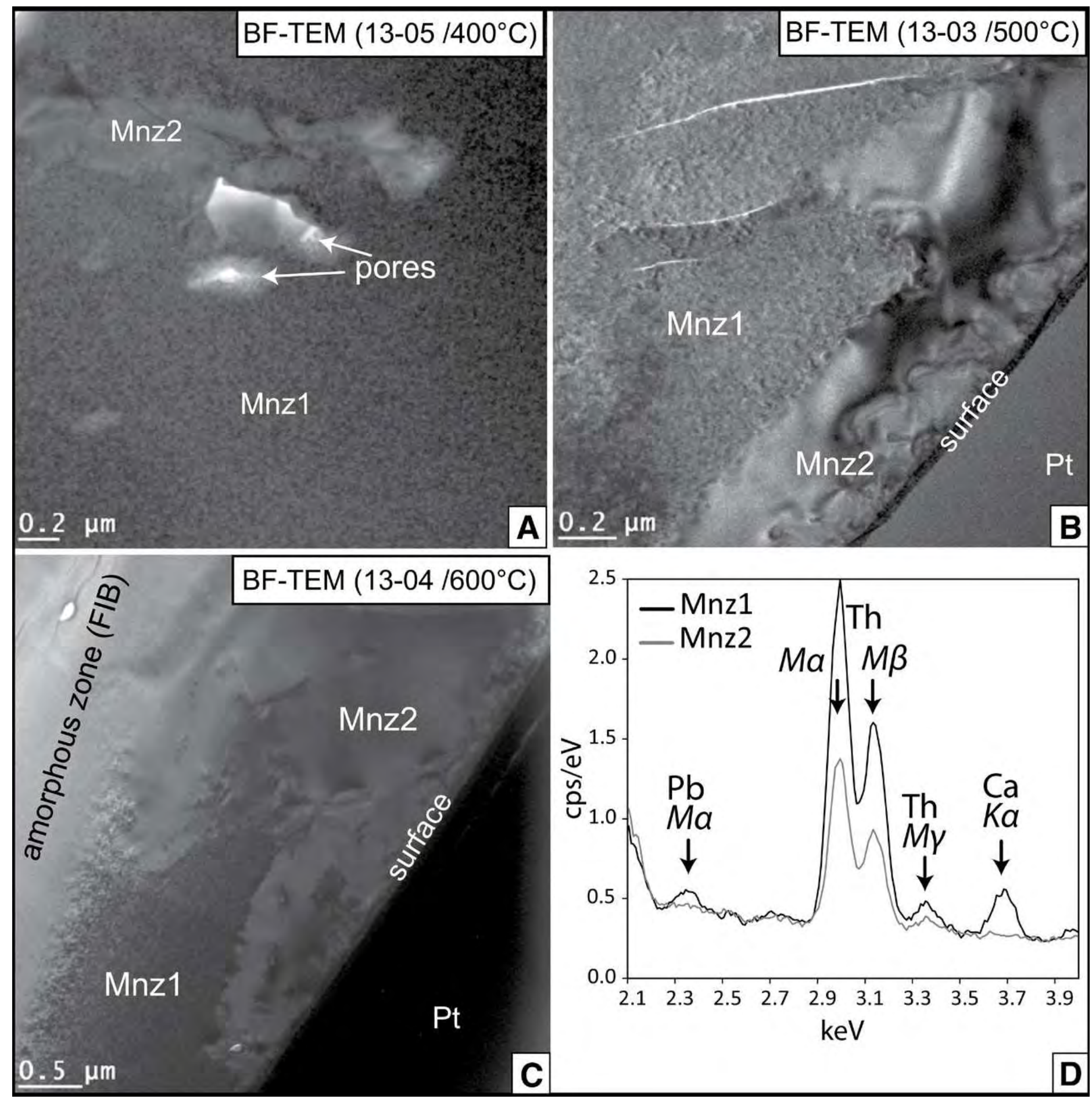

Grand'Homme et al. 2016

Fig. 12 


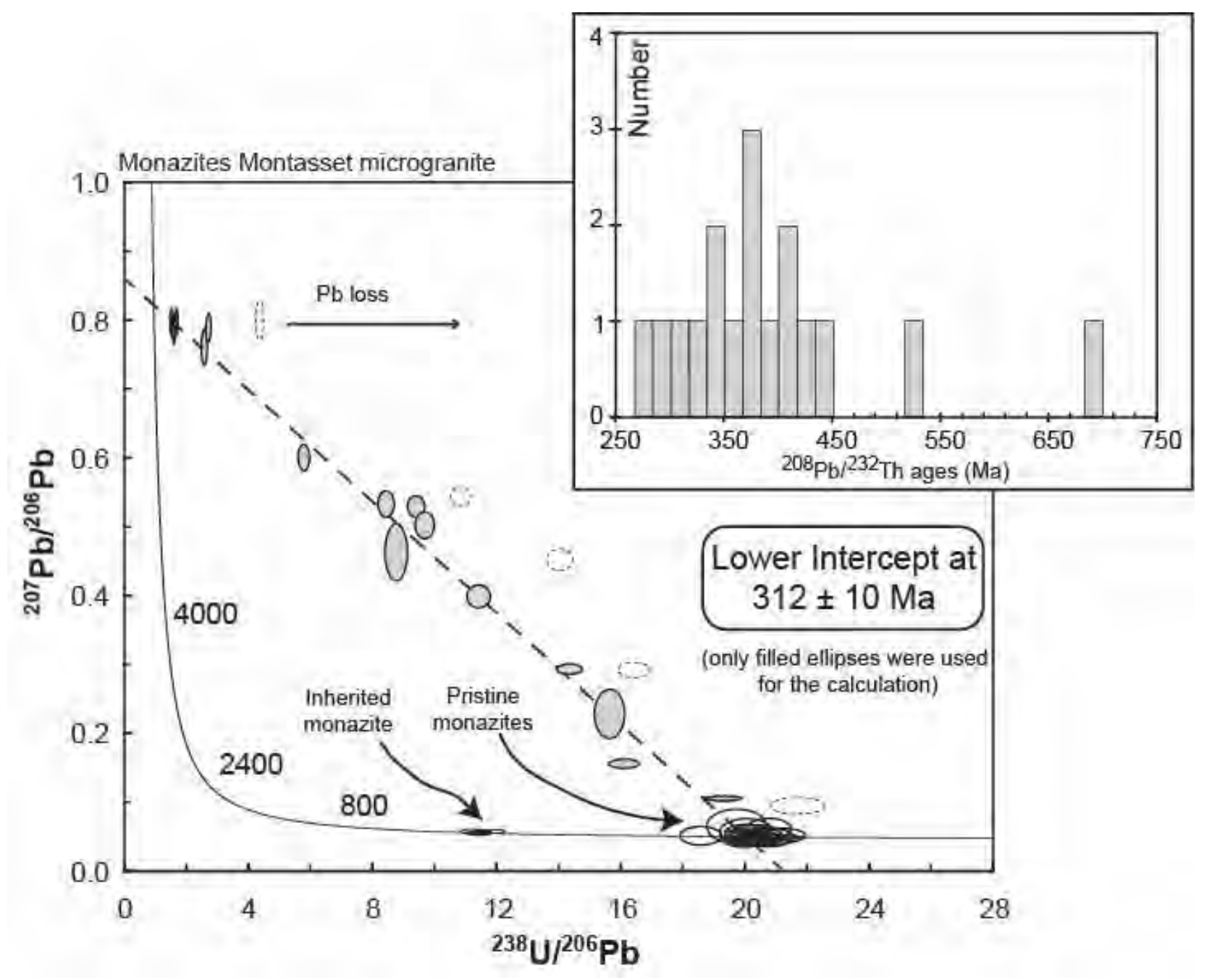

Tera-Wasserburg diagram of analyses in altered monazites (filled ellipses), in altered monazites affected by $\mathrm{Pb}$ loss (dashed ellipses), pristine monazites and an inherited monazite (empty ellipses) from the Montasset microgranite. Only altered monazites (filled ellipses) were used to calculate the $\mathrm{U}-\mathrm{Pb}$ age at $312 \pm 10 \mathrm{Ma}$. In the right corner: 208Pb/232Th age probability histogram for all alteredFig. 13 monazites (Didier et al. 2013) 